Article

\title{
Supermagnetic Nano-Bifunctional Catalyst from Rice Husk: Synthesis, Characterization and Application for Conversion of Used Cooking Oil to Biodiesel
}

\author{
Balkis Hazmi ${ }^{1}$, Umer Rashid ${ }^{1, *(D)}$, Yun Hin Taufiq-Yap ${ }^{2,3}$, Mohd Lokman Ibrahim ${ }^{4,5}$ and \\ Imededdine Arbi Nehdi 6,7 \\ 1 Institute of Advanced Technology, Universiti Putra Malaysia, Serdang 43400 UPM, Selangor, Malaysia; \\ balkishazmi95@gmail.com \\ 2 Chancellery Office, Universiti Malaysia Sabah, Kota Kinabalu 88400, Sabah, Malaysia; taufiq@upm.edu.my \\ 3 Catalysis Science and Technology Research Centre, Faculty of Science, Universiti Putra Malaysia, \\ Serdang 43400 UPM, Selangor, Malaysia \\ 4 School of Chemistry and Environment, Faculty of Applied Sciences, Universiti Teknologi MARA, \\ Shah Alam 40450, Selangor, Malaysia; mohd_lokman@uitm.edu.my \\ 5 Centre of Nanomaterial Research, Institute of Sciences, Universiti Teknologi MARA, Shah Alam 40450, \\ Selangor, Malaysia \\ 6 Chemistry Department, College of Science, King Saud University, Riyadh 1145, Saudi Arabia; \\ imed12002@gmail.com \\ 7 Laboratoire de Recherche LR18ES08, Chemistry Department, Science College, Tunis El Manar University, \\ Tunis 2092, Tunisia \\ * Correspondence: umer.rashid@upm.edu.my or umer.rashid@yahoo.com; Tel.: +60-3-9769-7393
}

Received: 27 November 2019; Accepted: 17 December 2019; Published: 13 February 2020

check for updates

\begin{abstract}
The present work investigated the biodiesel production from used cooking oil catalyzed by nano-bifunctional supermagnetic heterogeneous catalysts $\left(\mathrm{RHC} / \mathrm{K}_{2} \mathrm{O} / \mathrm{Fe}\right)$ derived from rice husk doped with $\mathrm{K}_{2} \mathrm{O}$ and $\mathrm{Fe}$ synthesized by the wet impregnation method. The synthesized catalysts $\left(\mathrm{RHC} / \mathrm{K}_{2} \mathrm{O} / \mathrm{Fe}\right.$ ) were characterized for crystallinity by X-ray diffraction spectroscopy (XRD), total acidity and basicity using $\mathrm{CO}_{2} / \mathrm{NH}_{3}-\mathrm{TPD}$, textural properties through Brunauer-Emmett-Teller (BET), thermal stability via thermogravimetric analyzer (TGA), functional group determination by Fourier-transform infrared spectroscopy (FTIR), surface morphology through field emission scanning electron microscopy (FESEM), and magnetic properties by vibrating sample magnetometer (VSM). The VSM result demonstrated that the super-paramagnetic catalyst $\left(\mathrm{RHC} / \mathrm{K}_{2} \mathrm{O}-20 \% / \mathrm{Fe}-5 \%\right)$ could be simply separated and regained after the reaction using an external magnetic field. The operating conditions such as catalyst loading, methanol/oil molar ratio, temperature, and reaction duration were studied. The screened $\mathrm{RHC} / \mathrm{K}_{2} \mathrm{O}-20 \% / \mathrm{Fe}-5 \%$ catalyst was selected for further optimization and the optimum reaction parameters found were $4 \mathrm{wt} \%$ of catalyst, a molar ratio of methanol/oil of 12:1, $4 \mathrm{~h}$ reaction duration, and $75{ }^{\circ} \mathrm{C}$ reaction temperature with a maximal yield of $98.6 \%$. The reusability study and reactivation results revealed that the nano-bifunctional magnetic catalyst ( $\left.\mathrm{RHC} / \mathrm{K}_{2} \mathrm{O}-20 \% / \mathrm{Fe}-5 \%\right)$ could be preserved by high catalytic activity even after being reused five times.
\end{abstract}

Keywords: rice husk; nano-magnetic catalyst; heterogeneous catalyst; used cooking oil; biodiesel

\section{Introduction}

An increasing supply of petrochemical resources to fulfill the high energy demands for industrialization and metropolitan growth over the last decades has caused the depletion of non-renewable conventional fuels $[1,2]$. The emission of toxic gases from the burning of fossil 
fuels can cause serious health effects and environmental problems [3]. In addition, the fluctuation of global petroleum prices and the emission of greenhouse gases (GHG) have initiated the search for alternative fuels from renewable resources [4]. Thus, biodiesel is a suitable source of energy which is sustainable, ecologically safe, and non-toxic as an alternative to replace fossil-based fuels [5].

The triglycerides of used cooking oil can chemically convert into biodiesel through transesterification with alcohols (methanol and ethanol) in the presence of homogeneous or heterogeneous catalysts Recently, used cooking oil (UCO) has recognized as an option towards cheap and discarded feedstock for the production of biodiesel to replace the high-priced vegetable and food oils raw materials, such as soybean oil, palm oil, canola oil, and sunflower oil [6]. It is estimated that the price of used cooking oil is approximated to be around half or less than half of the price of virgin cooking oil. In addition, utilization of used cooking oil or discarded oil can decrease the dependency on food oils for the production of biodiesel, and it can help to resolve the food versus fuel competition [7]. The used cooking oil (UCO) is considered as one of the waste oils, and its vast quantity is available all over the world, which is generated locally from restaurants and food manufactures. The improper ways of handling UCO can create a major disposal issue which is the source of pollution of land and water resources; that is why using UCO as a source for biodiesel synthesis could not only helps in the disposal or reduction of pollution but also can reduce the biodiesel production cost which could be a valuable addition of energy in the existing energy grid [1].

The use of conventional homogeneous catalysts has a complication in separation after the reaction, which tends to emulsification of UCO, requires a large amount of water for biodiesel purification, and recovery of catalyst is not possible [8]. The application of a homogeneous base catalyst for the transesterification process with low-cost and discarded feedstock which contains high free fatty acid content, i.e., UCO is unfavorable because the chemical reaction has a tendency for soap formation and slowly reverts the reaction backward, subsequently reducing the biodiesel yield [9]. Recently, the major drawbacks of homogeneous catalyst have been overcome by the development of heterogeneous catalyst which can be easily recovered from the reaction mixture by filtration, is recyclable, eco-friendly, and cuts off the need for neutralization which can reduce the cost of production [10]. Heterogeneous catalysts can be categorized into solid acid catalyst such as $\mathrm{AC}-\mathrm{Fe}_{(5)}-\mathrm{SO}_{3} \mathrm{Cl}$ [3], $\mathrm{SO}_{3} \mathrm{H}-\mathrm{ZnAl}_{2} \mathrm{O}_{4}$ [11], $\mathrm{Go}^{-} \mathrm{Fe}_{2} \mathrm{O}_{3}-\mathrm{SO}_{3} \mathrm{H}$ [12] and basic solid catalyst, for example, $\mathrm{Sr} / \mathrm{MgO}$ [13], $\mathrm{MgO} / \mathrm{MgAl}_{2} \mathrm{O}_{4}$ [14] and $\mathrm{K}_{2} \mathrm{O}-\mathrm{KCl}$ alkaline catalyst [15]. Although heterogeneous catalysts have many advantages, the application of solid catalysts for transesterification reaction is still limited, owing to the low availability of active sites for the catalytic activity to occur [16]. In addition, it needs a high reaction temperature and pressure to perform, unlike the commonly used homogeneous catalysts [17]. Besides that, catalyst deactivation through coking, sintering, poisoning, and leaching of active catalytic sites in the reaction medium are the common difficulty facing by heterogeneous catalysts, which will affect the catalytic performance for the next reaction cycle [18].

In the past few years, the application of nanoparticles as catalyst has gained considerable attention because of their nano-dimension and morphological structure with large surface area that consists of higher number of active sites [19] and pore size with high surface-volume ratio that enhance the selectivity and produce higher catalytic activity compared to the normal heterogeneous catalyst [20]. The incorporation of nano-magnetic particles such as ferrite ion through impregnation, precipitation, co-precipitation, and sol-gel method as a supporting agent to the solid catalyst aids in the easy separation between the catalyst and reaction media after the transesterification process [21]. The biodiesel conversion of canola oil through transesterification by using $9.03 \mathrm{wt} \%$ of magnetic mesoporous $\mathrm{KOH} / \mathrm{ZMS}-5-\mathrm{Fe}_{3} \mathrm{O}_{4}$ at $65^{\circ} \mathrm{C}$ reaction temperature, 12.3 molar ratio of alcohol to oil for $3.26 \mathrm{~h}$ resulted in $93.65 \%$ of biodiesel [22]. The nano-magnetic $\mathrm{ZnO} / \mathrm{BiFeO}_{3}$ catalyst showed highly catalytic performance in transesterification in which the FAME/biodiesel yield was more than $92.08 \%$ even after the use of five times under optimum reaction conditions (molar ratio of methanol/canola oil of 15:1, temperature of $65^{\circ} \mathrm{C}$, and a catalyst amount of $4 \mathrm{wt} \%$ ) [23]. 
The world rice production is estimated at 700 million tons every year [24], with approximately $20 \%$ of the paddy production is paddy residue such as rice husk (RH) and rice straw (RS) [25]. According to the statistic compiled by the Malaysian Ministry of Agricultural, the estimated amount of rice husk produced in Malaysia is 0.48 tons generated during the harvesting and milling processes [26]. In Malaysia, RH is mostly used as a fuel boiler for generating power for sugar industries and drying wet paddy. Unfortunately, the disposal problem of RH has risen due to the closure of power generation operations of sugar industries in northern Malaysia since 2012 [27]. Thus, a bulk quantity of unused $\mathrm{RH}$ is left or generally charred in the open fields. The burning practice of RH waste will lead to air pollution, and the airborne particles have been linked to respiratory diseases in humans [28] Activating the rice husk in the inert condition under nitrogen flow produces a highly porous carbon with a very high surface area that is good for catalytic applications. RH consists of $15 \mathrm{wt} \%$ silica [29], $30 \mathrm{wt} \%$ lignin, $65 \mathrm{wt} \%$ holo-cellulose and $5 \mathrm{wt} \%$ extracts [30]. Chen et al. reported that the $\mathrm{RH}$ and its ash have concerned immense attention for the extraction of silica $\left(\mathrm{SiO}_{2}\right)$ component, which could act as cheap sources for catalyst's precursor [31], to form stable and much effective metal/Si and composite for the transesterification reaction [29] such as $\mathrm{Li}_{2} \mathrm{CO}_{3} / \mathrm{RHA}$ [32] and rice husk-derived sodium silicate [33]. Indeed, the use of RH-derived biochar could be an efficient catalyst support for biodiesel production, but it can also resolve the issue of utilization of generated waste $\mathrm{RH}$ to a valuable product.

Over the past decade, the use of activated carbon (AC) as a catalyst or catalyst precursor for the production of biodiesel has become popular due to its significant surface area accessible for physisorption or chemisorption [34]. Moreover, carbon as a catalyst precursor has numerous advantages, i.e., high stability in both acidic and basic media, ease in the recovery of metals doped on it, and flexible to tailor its textural and surface chemical properties [35]. Biochar is organic solid char that is rich with carbon content with porous nature, which is formed through the pyrolysis or thermal decomposition of the biomass under the flow of nitrogen gas. Biochar surface consists of functional groups which could be modified with several other functional groups via functionalization step [36].

Previously, magnetic carbonaceous basic catalyst derived from Jatropha hull $\left(\mathrm{Na}_{2} \mathrm{SiO}_{3} @ \mathrm{Ni} / \mathrm{JRC}\right)$ was used as catalyst for biodiesel production from Jatropha oil with a high biodiesel yield of $96.7 \%$ under optimum conditions ( $7 \mathrm{wt} \%$ catalyst, $9: 1$ methanol/oil ratio for $2 \mathrm{~h}$ reaction duration at $65^{\circ} \mathrm{C}$ ) [37]. Sano et al. [38] reported that the $\mathrm{Ca}_{2} \mathrm{Fe}_{2} \mathrm{O}_{5}-\mathrm{CHN} / / \mathrm{CO}_{2}$ catalyst was able to produce FAME yield up to $100 \%$ for three times of catalyst reusability before the conversion dropped to $86.6 \%$ after the fifth cycle due to formation of calcium glyceroxide that led to catalyst deactivation. The purpose of this study was to synthesize nano-magnetic bifunctional heterogeneous catalysts derived from rice husk char (RHC) for conversion of biodiesel from used cooking oil. The physical and chemical properties of the resulting catalysts were characterized by using X-ray diffraction spectroscopy (XRD), Brunauer-Emmett-Teller (BET), temperature programmed desorption-carbon dioxide (TPD- $\left.\mathrm{CO}_{2}\right)$, temperature programmed desorption-ammonia (TPD-NH ${ }_{3}$ ), thermogravimetric analysis-differential thermal analysis (TGA-DTA), Fourier-transform infrared spectroscopy (FTIR), field emission scanning electron microscopy with energy dispersive X-Ray spectroscopy (FESEM-EDX), and vibrating sample magnetometer (VSM). The influence of catalyst preparation conditions on the RHC and the effects of the operating parameters on the transesterification reaction of UCO in terms of obtained biodiesel yield and reuse of the catalyst, were evaluated. Furthermore, a detailed of spent supermagnetic nano-bifunctional catalyst was also performed. The biodiesel confirmation was tested using ${ }^{1} \mathrm{H}-\mathrm{NMR}, \mathrm{FTIR}$, and discussed.

\section{Results and Discussion}

\subsection{Characterization of Supermagnetic Nano-Bifunctional Catalysts}

\subsubsection{Crystallinity Investigation}

The X-ray diffraction (XRD) pattern of rice husk char (RHC) and supermagnetic nano-bifunctional catalysts are depicted in Figure 1 and the diffraction peaks were identified using the standard ICSD file. A broad diffraction peak within $5.0^{\circ}$ to $35.0^{\circ}$ of RHC was attributed to amorphous carbon 
with randomly oriented carbon sheets [39]. The two additional peaks of $44.2^{\circ}$ and $64.6^{\circ}$ on RHC corresponded to the characteristic peaks of $\mathrm{SiO}_{2}$ with the monoclinic phase (ICSD File No. 01-083-1413) that consisted of more ordered graphite-like carbon lattice structure [40]. After loading of $\mathrm{K}_{2} \mathrm{CO}_{3}$ and $\mathrm{FeCl}_{3}$ with different concentrations, intensities of the main peaks of RHC decreased gradually and more new peaks exhibited in the XRD pattern. $\mathrm{K}_{2} \mathrm{O}$ peaks appeared at $2 \theta: 13.3^{\circ}$ (ICSD File No. 00-039-1380), 28.8 (ICSD File No. 01-018-0994) and 50.6 (ICSD File No. 00-019-0927). The peak of

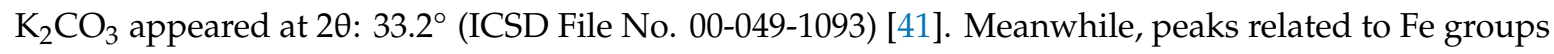
were located at $2 \theta: 31.8^{\circ}$ of $\alpha-\mathrm{Fe}_{2} \mathrm{O}_{3}$ (ICSD File No. 01-088-2359), 41.0 $0^{\circ}$, and $45.2^{\circ}$ of $\mathrm{Fe}_{2} \mathrm{O}_{3}$ (ICSD File No.01-075-0449). Both crystal systems of $\alpha-\mathrm{Fe}_{2} \mathrm{O}_{3}$ and $\mathrm{Fe}_{2} \mathrm{O}_{3}$ were rhombohedral. The intensities of potassium and iron were increased gradually as the dopants' concentrations varied from $20 \%$ to $30 \%$ and $5 \%$ to $10 \%$, respectively [29]. The XRD pattern of RHC/ $\mathrm{K}_{2} \mathrm{O}-20 / \mathrm{Fe}-10 \%$ clearly showed that the small diffraction peak of $\mathrm{K}_{2} \mathrm{CO}_{3}$ compared to other catalysts due to the surface of $\mathrm{K}_{2} \mathrm{CO}_{3}$ particles were dispersed and hindered by Fe particles due to which the X-ray beam unable to diffract on catalysts' surface [42]. Small peaks of Potassium Iron Silicate $\left(\mathrm{K}_{2} \mathrm{Fe}_{2} \mathrm{SiO}_{29}\left(\mathrm{O}_{4}\right)_{58}\right)$ and Potassium Iron Oxide $\left(\mathrm{K}_{3} \mathrm{FeO}_{2}\right)$ were observed at 20:66.8 (ICSD File No. 00-043-0264) and 74.6 ${ }^{\circ}$ (ICSD File No. 00-048-0957) with cubic and tetragonal phase respectively. Alternatively, the formation of both of the peaks was due to the interaction of $\mathrm{K}_{2} \mathrm{O}, \mathrm{Fe}_{2} \mathrm{O}_{3}$, and $\mathrm{SiO}_{2}$ substances on the catalyst during the calcination process [43].

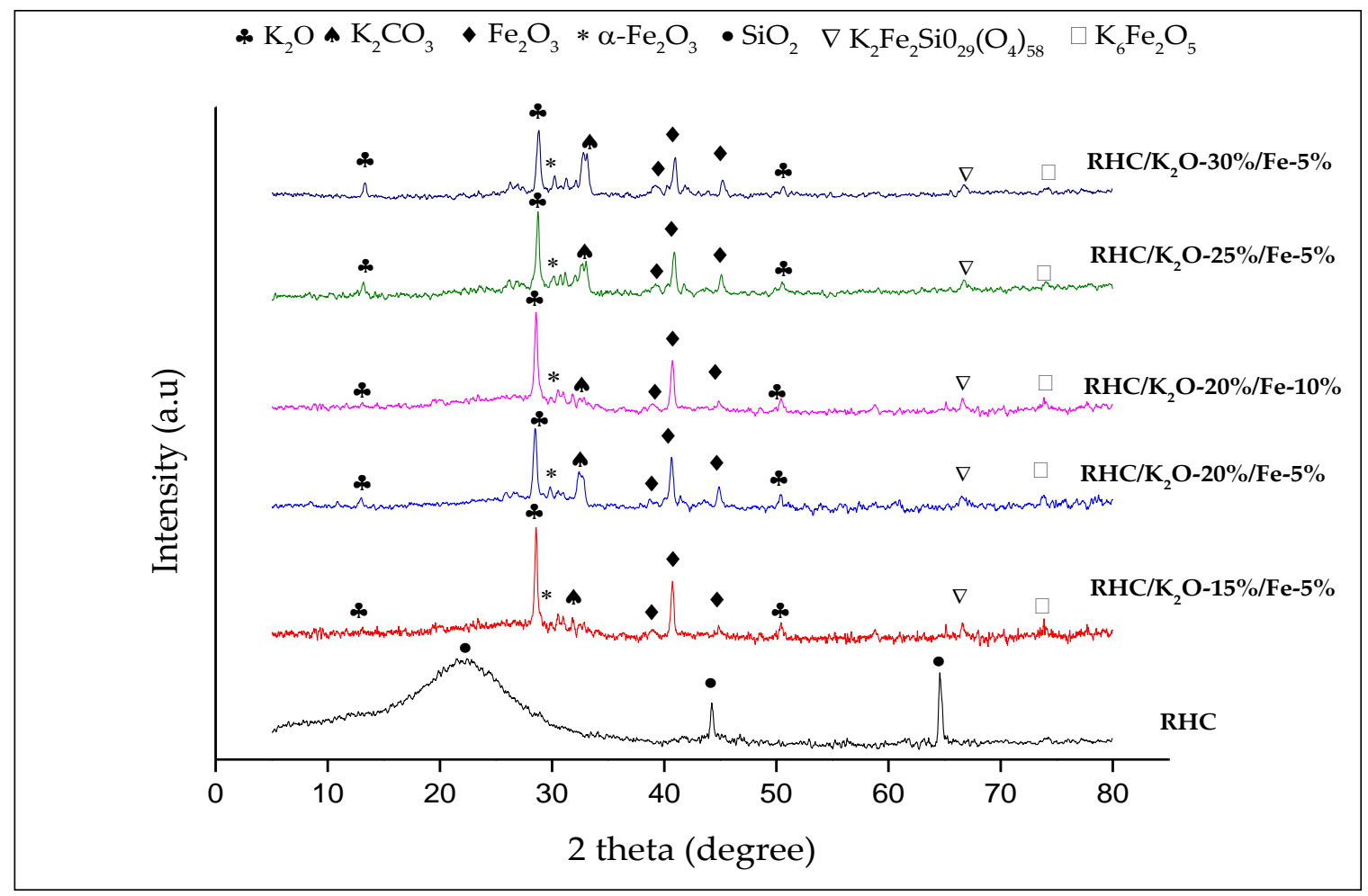

Figure 1. X-ray diffraction (XRD) patterns of rice husk char (RHC) and RHC-derived catalysts.

\subsubsection{Temperature Programmed Desorption (TPD)}

Both acidic and basic properties of $\mathrm{RH}, \mathrm{RHC}$, and RHC derived catalysts were determined using $\mathrm{CO}_{2}$ and $\mathrm{NH}_{3}-\mathrm{TPD}$, respectively, as tabulated in Table 1. Based on the results, the derived catalysts from RHC were exhibited as bifunctional properties that consisted of both basic and acid sites. The patterns showed major $\mathrm{CO}_{2}$ and $\mathrm{NH}_{3}$ desorption at various degrees of temperature that indicated the level of the basic and acidic strength of the catalyst. The peaks that appeared below $360^{\circ} \mathrm{C}$ represented a weak desorption site [44] while peaks of moderate and strong desorption site arose at between $360^{\circ} \mathrm{C}$ and $700{ }^{\circ} \mathrm{C}$ and above $700{ }^{\circ} \mathrm{C}$, respectively [45]. 
Table 1. Textural properties and total desorption of $\mathrm{CO}_{2}$ and $\mathrm{NH}_{3}$ for $\mathrm{RH}, \mathrm{RHC}$, and $\mathrm{RHC} / \mathrm{K}_{2} \mathrm{O} / \mathrm{Fe}$.

\begin{tabular}{|c|c|c|c|c|c|c|}
\hline \multirow{2}{*}{ Catalyst } & \multirow{2}{*}{$\mathrm{S}_{B E T}\left(\mathrm{~m}^{2} \mathrm{~g}^{-1}\right)^{\mathrm{a}}$} & \multirow{2}{*}{$\mathrm{D}_{p}(\mathrm{~nm})^{\mathrm{b}}$} & \multirow{2}{*}{$\mathrm{V}_{p}\left(\mathrm{~cm}^{3} \mathrm{~g}^{-1}\right)^{\mathrm{c}}$} & TPD-CO $\mathrm{CO}_{2}$ & ${\mathrm{TPD}-\mathrm{NH}_{3}}_{3}$ & \multirow{2}{*}{$\begin{array}{l}\text { FAME Yield } \\
(\%)^{d}\end{array}$} \\
\hline & & & & $\begin{array}{c}\text { Total Basicity } \\
\left(\mathrm{mmolg}^{-1}\right)\end{array}$ & $\begin{array}{l}\text { Total Acidity } \\
\left(\text { mmolg }^{-1}\right)\end{array}$ & \\
\hline RH & 3.97 & 5.30 & 0.0097 & 2.07 & 15.57 & No reaction \\
\hline RHC & 203.54 & 4.09 & 0.1644 & 2.71 & 37.34 & No reaction \\
\hline $\mathrm{RHC} / \mathrm{K}_{2} \mathrm{O}-15 \% / \mathrm{Fe}-5 \%$ & 76.06 & 4.52 & 0.0632 & 3.34 & 37.36 & 67.29 \\
\hline $\mathrm{RHC} / \mathrm{K}_{2} \mathrm{O}-20 \% / \mathrm{Fe}-5 \%$ & 57.89 & 4.70 & 0.0588 & 4.43 & 24.59 & 78.41 \\
\hline $\mathrm{RHC} / \mathrm{K}_{2} \mathrm{O}-20 \% / \mathrm{Fe}-10 \%$ & 41.17 & 4.15 & 0.0486 & 2.07 & 30.15 & No reaction \\
\hline $\mathrm{RHC} / \mathrm{K}_{2} \mathrm{O}-25 \% / \mathrm{Fe}-5 \%$ & 36.17 & 4.98 & 0.0474 & 2.69 & 17.22 & 75.27 \\
\hline $\mathrm{RHC} / \mathrm{K}_{2} \mathrm{O}-30 \% / \mathrm{Fe}-5 \%$ & 27.62 & 4.77 & 0.0343 & 2.54 & 11.87 & 77.59 \\
\hline
\end{tabular}

${ }^{a}$ Specific surface area; ${ }^{b}$ Average pore diameter; ${ }^{c}$ Total pore volume at $\mathrm{p} / \mathrm{po}=0.99 ;^{\mathrm{d}}$ Reaction condition (non-optimized): 10:1 methanol molar ratio, $3 \mathrm{wt} . \%$ catalyst, $65^{\circ} \mathrm{C}$ reaction temperature, $4 \mathrm{~h}$ reaction time.

Generally, RH and RHC exhibited weak and moderate strengths of base and acid properties with total desorption, with basic density of $2.07 \mathrm{mmol} \mathrm{g}^{-1}, 2.72 \mathrm{mmol} \mathrm{g}^{-1}$ and acidic density $15.57 \mathrm{mmol}$ $\mathrm{g}^{-1}, 15.01 \mathrm{mmol} \mathrm{g}^{-1}$, respectively. As the rice husk char was doped with $\mathrm{K}_{2} \mathrm{CO}_{3}$ (from $15 \%$ to $30 \%$ ) and $\mathrm{FeCl}_{3} \cdot 6 \mathrm{H}_{2} \mathrm{O}$ (from $5 \%$ to $10 \%$ ), the strength and total basicity and acidity increased significantly. TPD- $\mathrm{CO}_{2}$ analysis showed the desorption of $\mathrm{CO}_{2}$ gas at a temperature range of $550{ }^{\circ} \mathrm{C}$ to $850{ }^{\circ} \mathrm{C}$, which was maximized at around $707^{\circ} \mathrm{C}$ to $788^{\circ} \mathrm{C}$, could be considered as the strong strength of basic sites from $\mathrm{K}_{2} \mathrm{O}$. The basicity value of the synthesized catalyst loaded with $20 \%$ of potassium was significantly higher than lower $\mathrm{K}_{2} \mathrm{O}$ loading. Meanwhile, the further increment of $\mathrm{K}_{2} \mathrm{O}$ loading caused the total absorption-desorption of $\mathrm{CO}_{2}$ to reduce due to less interaction between the probe gas and fully covered active sites $[44,46]$. The same goes for the acidity properties of the catalysts; as the loading percentage of $\mathrm{K}_{2} \mathrm{O}$ increased, the total desorption of $\mathrm{NH}_{3}$ reduced. In addition, the basicity of $\mathrm{RHC} / \mathrm{K}_{2} \mathrm{O}-20 \% / \mathrm{Fe}-10 \%$ reduced after being doped with $10 \%$ of Fe due its acidity strength that suppressed the basic site that might neutralize the catalyst and cause no conversion of biodiesel to happen. Besides that, random distributions of excess agglomerated $\mathrm{Fe}(10 \% \mathrm{of} F)$ on the catalyst might cover the active K-active site on porous RHC support which imbalanced the basicity characteristic, also reduced the catalyst pore size that will prevent the penetration of methanol and triglyceride; hence, it discourage the transesterification to occur [47]. The excess phase of $\mathrm{K}_{2} \mathrm{O}$ and $\mathrm{Fe}_{2} \mathrm{O}_{3}$ on the surface of RHC support led to reduction of its porosity, hence decreasing the BET surface area [48]. The biodiesel yield depended on to the basicity of the catalyst where the higher the basicity, the greater the FAME formation, as stated in Table 1 , in which RHC/ $\mathrm{K}_{2} \mathrm{O}-20 \% / \mathrm{Fe}-5 \%$ showed better biodiesel yield among others. The further increment of dopant compounds will slightly reduce of catalytic activity of converting triglycerides into fatty acid methyl ester (FAME) which related to the mass transfer and poor mixing between reactants and catalyst performance [49-51]. Thus, magnetic $\mathrm{RHC} / \mathrm{K}_{2} \mathrm{O}-20 \% / \mathrm{Fe}-5 \%$ was chosen for further characterization analysis and catalyst optimization in biodiesel production.

\subsubsection{Surface Area and Porosity Measurement}

Textural properties of rice husk (RH), rice husk char (RHC) and magnetic RHC/ $\mathrm{K}_{2} \mathrm{O} / \mathrm{Fe}$ catalysts were evaluated by adsorption and desorption of $\mathrm{N}_{2}$ at $77 \mathrm{~K}$. Table 1 shows that the specific surface area for RH was $3.97 \mathrm{~m}^{2} \mathrm{~g}^{-1}$ whereas the surface is for RHC $203.54 \mathrm{~m}^{2} \mathrm{~g}^{-1}$ after being calcined was at $450{ }^{\circ} \mathrm{C}$. Carbonisation of biomass at high temperature can increase the carbon content and produce high porosity material [52]. A study conducted by Zhao [29] stated the use of potassium hydroxide in pre-treatment as a chemical activation agent to improve the surface area and pore diameter of RHC. A significant reduction of surface area from $203.54 \mathrm{~m}^{2} \mathrm{~g}^{-1}$ to $57.89 \mathrm{~m}^{2} \mathrm{~g}^{-1}$ may be due to the surface of catalyst precursor which was covered by potassium and ferric doping, and the decrement of pore volume from $0.1644 \mathrm{~cm}^{3} \mathrm{~g}^{-1}$ to $0.0588 \mathrm{~cm}^{3} \mathrm{~g}^{-1}$ was due to the blockage of catalyst pores which confirmed the impregnation of $\mathrm{K}$ and Fe on the catalyst's surface. As shown in Figure S1a, RH, RHC and RHC nano-magnetic catalysts exhibited a Type-IV adsorption isotherms at a lower $\mathrm{p} / \mathrm{p}^{0}$ values with narrow hysteresis loop of desorption, according to the International Union of Pure and Applied 
Chemistry (IUPAC) classification which proved the presence of mesoporous structure and may be characterized by the formation of slit-shaped pores [53].

The perfect transesterification reaction depends on the pore structure of the heterogeneous catalyst. The size of the distribution of the catalyst is shown in Figure S1b RHC, and RHC nano-magnetic catalysts demonstrated comparable pore size distributions in the mesoporous pore diameter distribution range of $2 \mathrm{~nm}$ to $50 \mathrm{~nm}$ [50]. Boz et al. [20] reported that the diameter of triglycerides and glycerol molecules was $2.5 \mathrm{~nm}$, which was small enough to pass through into the porous catalysts and would be employed throughout the transesterification reaction.

\subsubsection{Thermal Gravimetric Analysis}

The thermal stability of $\mathrm{RH}$ and $\mathrm{RHC} / \mathrm{K}_{2} \mathrm{O}-20 \% / \mathrm{Fe}-5 \%$ catalyst was ascertained by using thermogravimetric analysis (TGA)/differential thermal analysis (DTA) as presented in Figure 2. Three main stages of thermal decomposition consisted of removal of the adsorbed water molecule at a temperature below $100^{\circ} \mathrm{C}$, followed by the secondary stage of primary pyrolysis temperature range between $200{ }^{\circ} \mathrm{C}$ to $650{ }^{\circ} \mathrm{C}$ and the third phase of decomposition at high temperature over $700{ }^{\circ} \mathrm{C}$ [20], as shown in Figure 3.

The first stage of thermal decomposition of $\mathrm{RH}$ at the range of $26{ }^{\circ} \mathrm{C}$ to $136^{\circ} \mathrm{C}$ with a weight loss of $6.59 \%$ was associated with the elimination of adsorbed water molecule on the RH surface. The second phase with a temperature range of $152{ }^{\circ} \mathrm{C}$ to $303^{\circ} \mathrm{C}$ corresponded to the decomposition of hemicellulose and cellulose with a weight loss of $15.18 \%$. The degradation of lignin occurred at a higher temperature range from $303^{\circ} \mathrm{C}$ to $633^{\circ} \mathrm{C}$ with a major weight loss of $44.40 \%$. The leftover after $632{ }^{\circ} \mathrm{C}$ to $991^{\circ} \mathrm{C}$ was annotated as solid residue [54-56]. The TGA-DTA curves of RHC did not exhibit apparent mass loss event, which demonstrated that the synthesized RHC has good thermal stability. For the supermagnetic nano-bifunctional $\mathrm{RHC} / \mathrm{K}_{2} \mathrm{O}-20 \% / \mathrm{Fe}-5 \%$ catalyst, the first weight loss of $17.11 \%$ at about $26^{\circ} \mathrm{C}$ to $176{ }^{\circ} \mathrm{C}$ may be due to the elimination of adsorbed or chemisorbed $\mathrm{H}_{2} \mathrm{O}$ molecule [57]. Another weight loss of $3.65 \%$ between $523^{\circ} \mathrm{C}$ to $648^{\circ} \mathrm{C}$ was attributed to the dehydroxylation of $\mathrm{OH}$ ions of supermagnetic RHC nano-bifunctional catalysts as well as disintegrate of $\mathrm{FeCl}_{3}$ into its oxide $\left(\mathrm{Fe}_{2} \mathrm{O}_{3}\right)$. The decomposition of $\mathrm{K}_{2} \mathrm{CO}_{3}$ to $\mathrm{K}_{2} \mathrm{O}$ exhibited a major weight loss of $18.43 \%$ at a temperature range between $705^{\circ} \mathrm{C}$ to $1000{ }^{\circ} \mathrm{C}$.

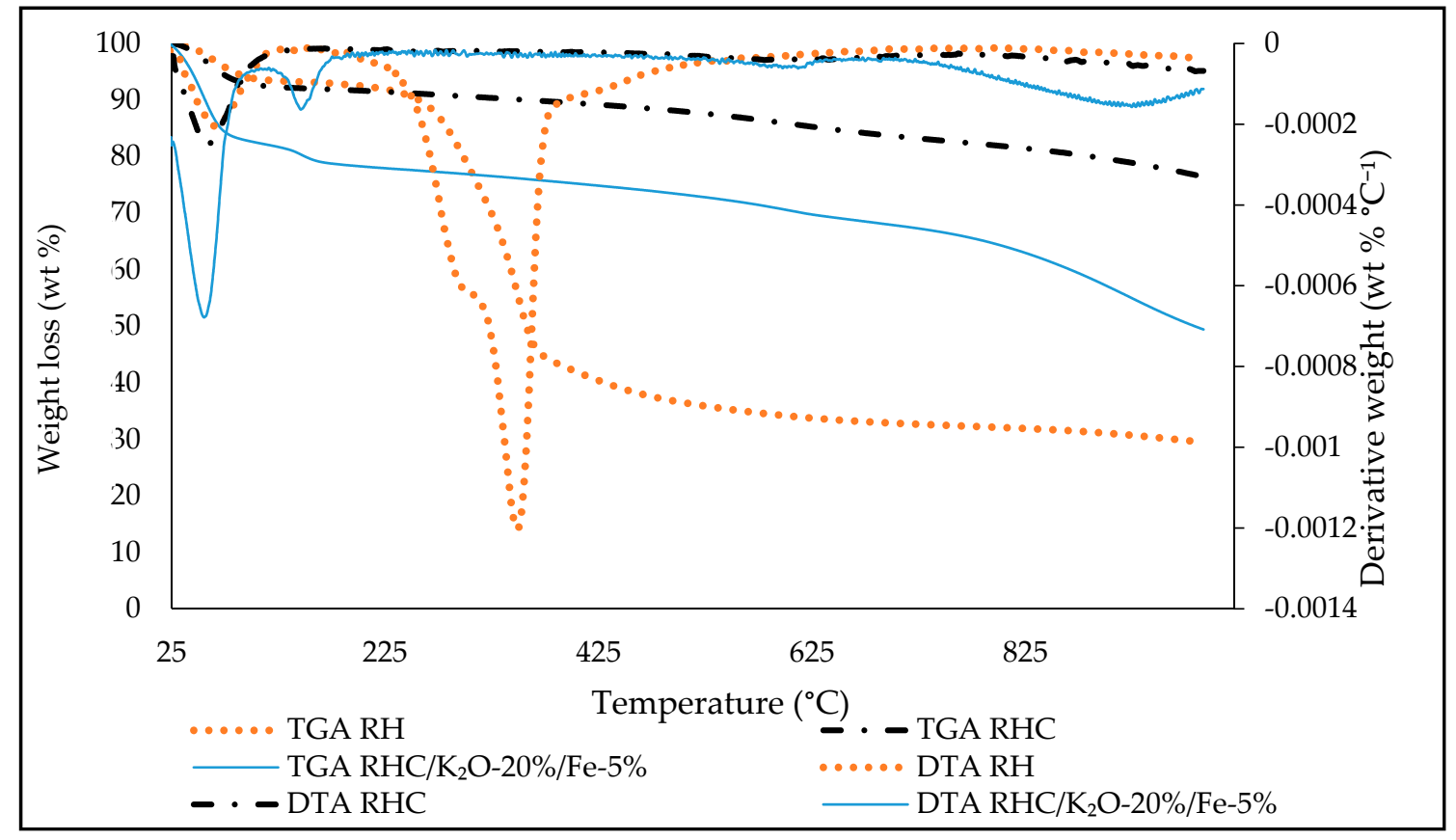

Figure 2. Thermogravimetric analysis- Differential thermal analysis (TGA-DTA) curves of the rice husk (RH), rice husk char (RHC) and nano-magnetic $\mathrm{RHC} / \mathrm{K}_{2} \mathrm{O}-20 \% / \mathrm{Fe}-5 \%$ catalysts. 


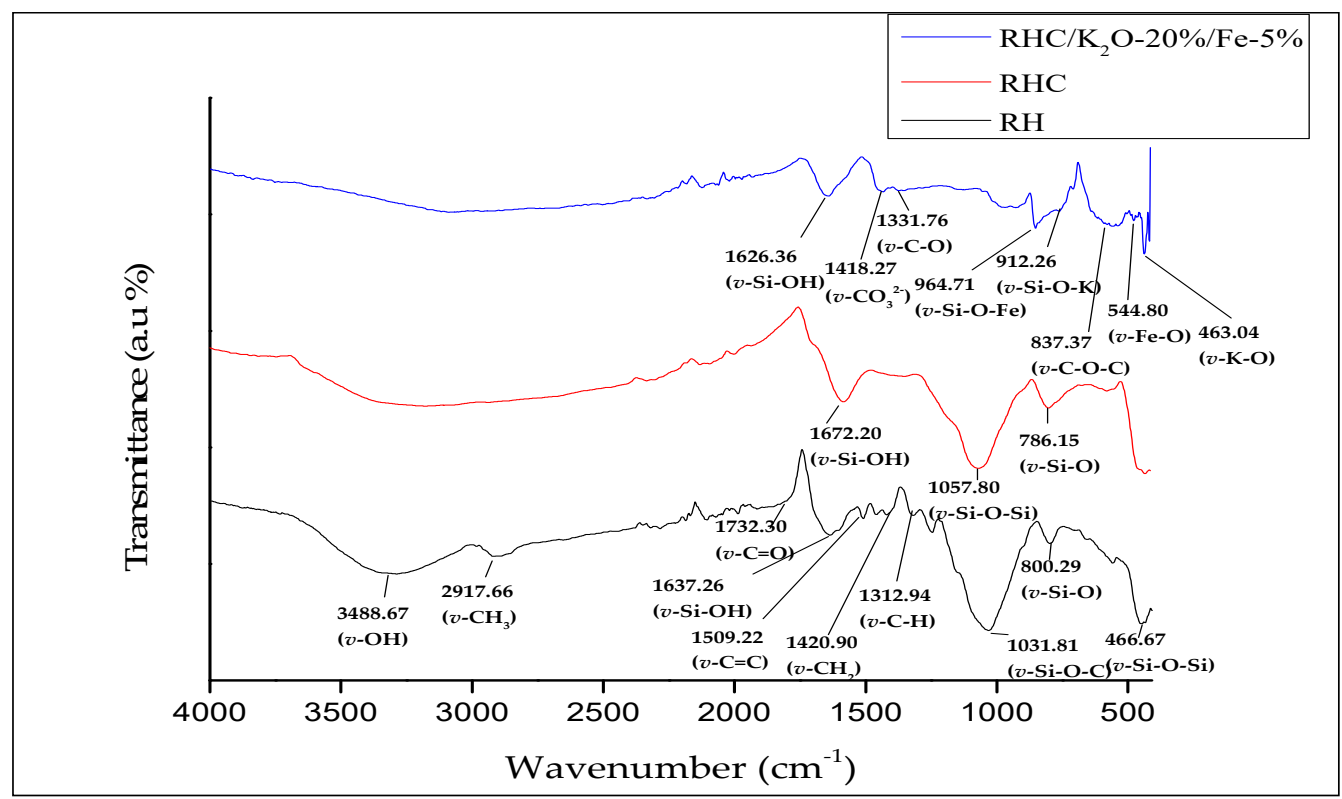

Figure 3. Fourier transform infrared (FTIR) spectra of RH, RHC and $\mathrm{RHC} / \mathrm{K}_{2} \mathrm{O}-20 \% / \mathrm{Fe}-5 \%$.

\subsubsection{Functional Group Analysis}

The Fourier Transform Infrared (FTIR) spectra of rice husk (RH), rice husk char (RHC), and supermagnetic RHC nano-bifunctional catalyst are illustrated in Figure 3. Broad absorption bands at range $3488.67 \mathrm{~cm}^{-1}$ to $3359.29 \mathrm{~cm}^{-1}$ and $1672.20 \mathrm{~cm}^{-1}$ to $1637.26 \mathrm{~cm}^{-1}$ corresponded to the hydroxyl group - $\mathrm{OH}$ and silanol, $\mathrm{Si}-\mathrm{OH}$ stretching and bending, respectively that indicated physisorption of a water molecule on the surface of $\mathrm{RH}, \mathrm{RHC}$ and magnetic $\mathrm{RHC} / \mathrm{K}_{2} \mathrm{O}-20 \% / \mathrm{Fe}-5 \%$ catalyst [58]. The band around $2917.66 \mathrm{~cm}^{-1}$ was assigned to the asymmetric and symmetric methylene stretching vibration of the saturated aliphatic compound present in the cellulose and hemicellulose of $\mathrm{RH}$ [59]. A spectra band around $1732.30 \mathrm{~cm}^{-1}$ was associated with the acetyl and ester group of the $\mathrm{C}=\mathrm{O}$ bond in hemicellulose while lignin infrared spectra appeared at $1509.22 \mathrm{~cm}^{-1}$, which represented $\mathrm{C}=\mathrm{C}$ aromatic vibration. The lignin absorption spectra characteristic was found at $1463.53 \mathrm{~cm}^{-1}$, and cellulose plane bending vibrations, $\mathrm{CH}_{2}$ of $\mathrm{RH}$ were clearly visible at $1420.90 \mathrm{~cm}^{-1}$. The spectra of $1312.94 \mathrm{~cm}^{-1}$ showed the $\mathrm{C}-\mathrm{H}$ deformation in $\mathrm{RH}^{\prime}$ s cellulose and hemicellulose. The high-intensity band spectrum around $1031.81 \mathrm{~cm}^{-1}$ was detected due to the asymmetric and symmetric band stretching of the $\mathrm{Si}-\mathrm{O}-\mathrm{C}$ and $\mathrm{Si}-\mathrm{O}-\mathrm{Si}$ bonds corresponding to the silica and the cellulose of $\mathrm{RH}$. The peaks related to lignin and cellulose disappeared in the RHC spectrum band after the RH calcination due to biomass degradation at high temperatures. New spectra band which corresponded to the asymmetrical stretching vibration of the siloxane, Si-O-Si bond was formed and slightly shifted to $1057.80 \mathrm{~cm}^{-1}$ of RHC after calcination of RH. A sharp peak of symmetric stretching vibration of Si-O and vibration-bending modes of the Si-O-Si bond appeared at $800.29 \mathrm{~cm}^{-1}$ and $466.67 \mathrm{~cm}^{-1}$ in both RH and RHC spectra respectively. The silica functional group spectra remained before and after the calcination process and provided a mesoporous structure for RHC as support [60]. A sharp and intense spectrum peak at $1418.36 \mathrm{~cm}^{-1}$ of $\mathrm{RHC} / \mathrm{K}_{2} \mathrm{O}-20 \% / \mathrm{Fe}-5 \%$ was attributed to the carbonate species from $\mathrm{K}_{2} \mathrm{CO}_{3}$ doped on the RHC support [40]. The peaks at $1331.76 \mathrm{~cm}^{-1}$ and $837.37 \mathrm{~cm}^{-1}$ were assigned to the stretching vibration $\mathrm{C}-\mathrm{O}$ and the deformation vibration of $\mathrm{C}-\mathrm{O}-\mathrm{C}$, respectively [61]. The weak vibration of $\mathrm{M}+-\mathrm{O}$ stretching adsorption bands at $544.80 \mathrm{~cm}^{-1}$, and $463.04 \mathrm{~cm}^{-1}$ belonged to $\mathrm{Fe}-\mathrm{O}$ and $\mathrm{K}-\mathrm{O}$ bonding, respectively [62].The deformation bands of $\mathrm{M}^{+}-\mathrm{OH}$ converted to $\mathrm{Si}-\mathrm{O}-\mathrm{M}^{+}$located at $964.71 \mathrm{~cm}^{-1}$ and $912.26 \mathrm{~cm}^{-1}$ were assigned to Fe and $\mathrm{K}$, respectively [63]. Upon the formation of $\mathrm{Si}-\mathrm{O}-\mathrm{M}^{+}$, the intensity of the siloxane absorption band was reduced and shifted to lower frequency due to the reduction of electron density [64]. 


\subsubsection{Morphological and Energy Dispersive X-ray Spectroscopy Analysis}

The surface morphologies of $\mathrm{RH}, \mathrm{RHC}$, and supermagnetic $\mathrm{RHC} / \mathrm{K}_{2} \mathrm{O}-20 \% / \mathrm{Fe}-5 \%$ nanobifunctional catalysts were studied using FESEM, as shown in Figure 4. Figure 4a shows that the RH sample consists of an external surface with a well-organized corrugated structure [54]. The asymmetrical porous layer of $\mathrm{RH}$ can be observed through the cross-section view with a magnification of 10,000×, as shown in Figure 4b. Highly porous structure with a large surface area of RHC, as shown in Figure 4c, was formed after carbonization due to thermal decomposition of organic material from $\mathrm{RH}$. Figure $4 \mathrm{~d}$ shows that nano-magnetic $\mathrm{RHC} / \mathrm{K}_{2} \mathrm{O}-20 \% / \mathrm{Fe}-5 \%$ catalyst was made up of the agglomeration of irregular small and large particles, mainly potassium and iron attached to the porous surface of the RHC precursor. The elemental compositions of RH, RHC, and nano-magnetic RHC/ $\mathrm{K}_{2} \mathrm{O}-20 \% / \mathrm{Fe}-5 \%$ were verified by energy-dispersive $\mathrm{X}$-ray spectroscopy analysis (EDX) with a detector mounted on a microscope. The RH was made up of $39.83 \mathrm{wt} \% \mathrm{C}, 53.29 \mathrm{wt} \% \mathrm{O}, 6.56 \mathrm{wt} \% \mathrm{Si}$ and a trace amount of $0.33 \mathrm{wt} \% \mathrm{~K}$. Meanwhile, the elemental compositions of RHC were; $61.07 \mathrm{wt} \% \mathrm{C}, 27.50 \mathrm{wt} \% \mathrm{O}, 9.76$ $\mathrm{wt} \% \mathrm{Si}$ and $1.67 \mathrm{wt} \% \mathrm{~K}$ after carbonization and pre-treatment process. The nano-magnetic catalyst consisted $41.02 \mathrm{wt} \% \mathrm{C}, 27.25 \mathrm{wt} \% \mathrm{O}, 3.60 \mathrm{wt} \% \mathrm{Si}, 21.34 \mathrm{wt} \% \mathrm{~K}$, and $2.01 \mathrm{wt} \%$ Fe. The interaction between $\mathrm{K}$ and $\mathrm{Fe}$ of the prepared catalyst resulted in a well-developed porous structure believed to have contributed to its high catalytic activity. It was observed that the presence of $\mathrm{K}$ indicated a high basicity of prepared catalyst, which can contribute to the transesterification of used cooking oil. Also, the high oxygen atomic percentage suggested that the metallic and synergetic compound formed consisted of oxygen atom mainly bonded to the KFeSi composite rather than being bonded to individual metal oxides. The experimental weight percentage of potassium in nano-magnetic catalyst exceeded its theoretical weight due to the amount of potassium from the pre-treatment process that was not completely washed off from RHC.

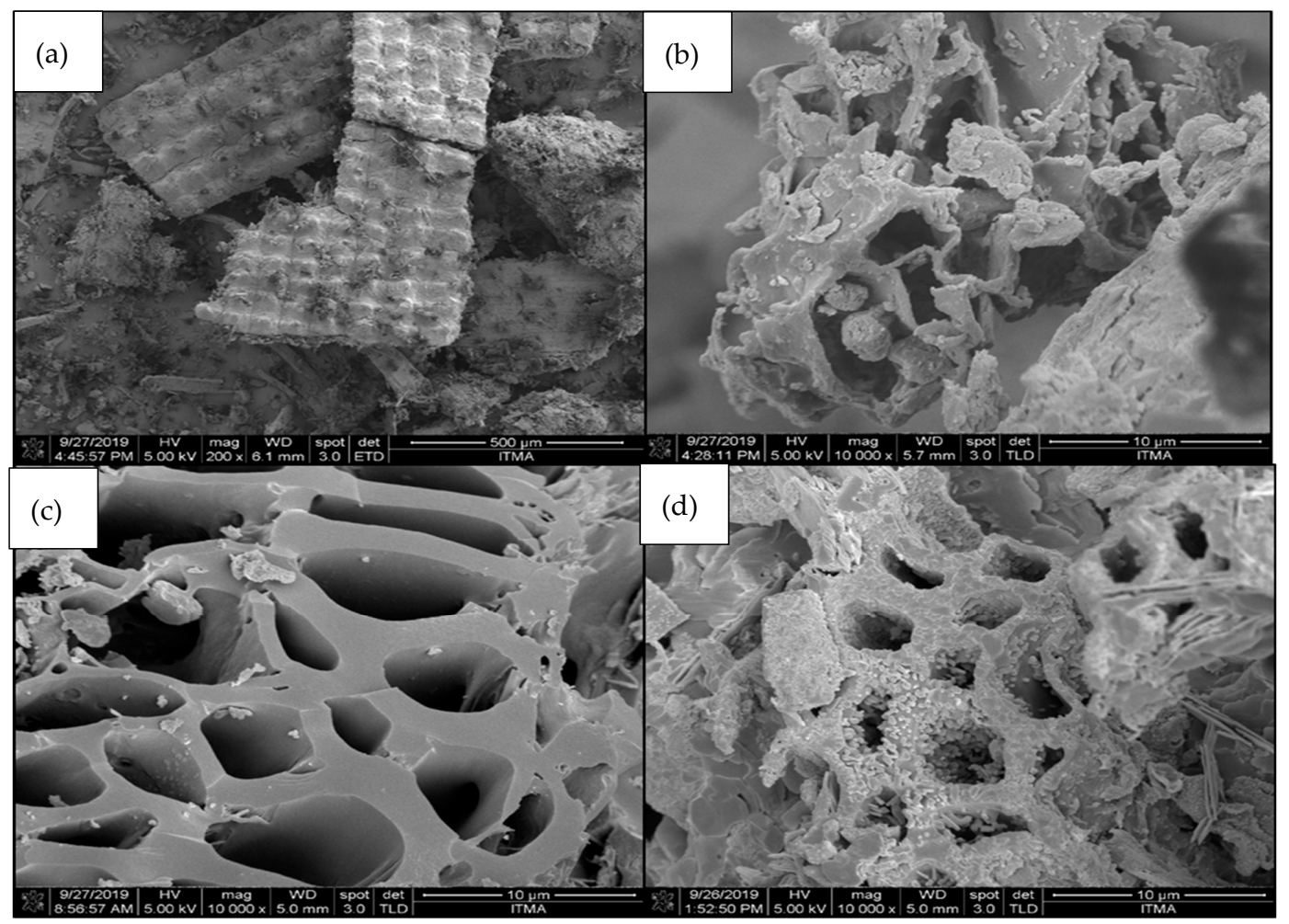

Figure 4. Field emission scanning electron microscopy (FESEM) image; (a) External surface RH (200×), (b) Cross-section view of RHC (10,000×), (c) RHC (10,000×), (d) Nano-magnetic RHC/K2O-20\%/Fe-5\% catalyst $(10,000 \times)$. 


\subsubsection{Vibrating Sampling Magnetometer Analysis}

The magnetic property of $\mathrm{RHC} / \mathrm{K}_{2} \mathrm{O}-20 \% / \mathrm{Fe}-5 \%$ was studied using a vibrating sampling magnetometer (VSM), as shown in Figure 5. The M-H loops of fresh magnetic catalyst showed strong magnetization of $7.88 \mathrm{emug}^{-1}$, and there was a closed hysteresis loop of the catalysts which can be concluded as a superparamagnetic material at room temperature that can be easily separated from the biodiesel reaction system by introducing an external magnet $[61,65]$.

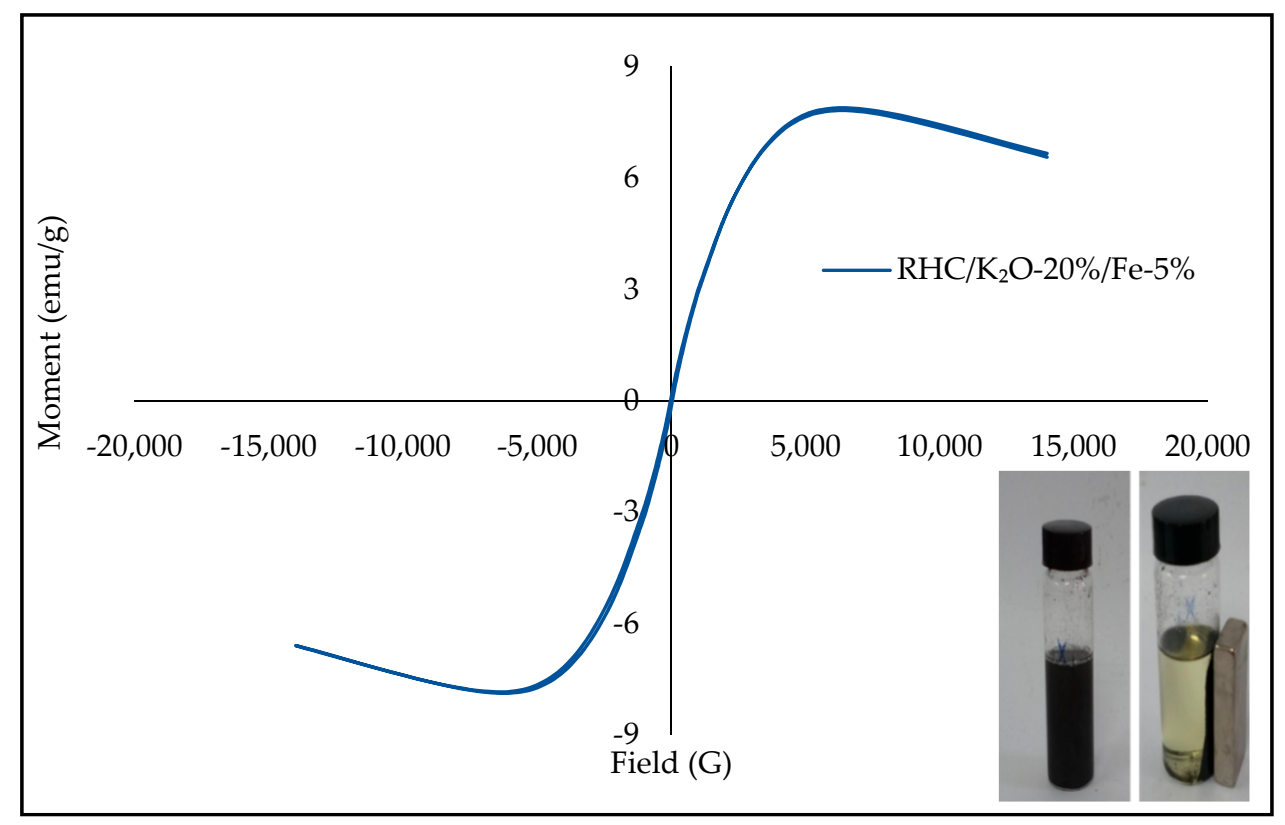

Figure 5. Vibrating sample magnetometer (VSM) magnetization curve of $\mathrm{RHC} / \mathrm{K}_{2} \mathrm{O}-20 \% / \mathrm{Fe}-5 \%$ catalyst and the magnetic separation of the catalyst from biodiesel.

\subsection{Influence of Process Parameters on the Transesterification of Used Cooking Oil}

\subsubsection{Effects of Catalyst Amount for Catalyst Screening and Catalytic Performance}

The catalytic activity of transesterification of used cooking oil (UCO) was carried out in the presence of synthesized catalysts at the following reaction conditions; methanol to oil molar ratio of 10:1 at a temperature of $65^{\circ} \mathrm{C}$, for $4 \mathrm{~h}$ with various catalyst loadings of 1 to $8 \mathrm{wt} \%$ (Figure 6). Among the four catalysts tested, the $\mathrm{RHC} / \mathrm{K}_{2} \mathrm{O}-20 \% / \mathrm{Fe}-5 \%$ presented the best reaction activity and produced the highest yield of $91.8 \%$; thus, all the optimizations were carried out with this catalyst material. The presence of optimum strength for both acidic and basic properties on the surface of catalysts could affect the formation of highly reactive methoxide species in transesterification. The catalyst of $\mathrm{RHC} / \mathrm{K}_{2} \mathrm{O}-15 \% / \mathrm{Fe}-5 \%$, RHC $/ \mathrm{K}_{2} \mathrm{O}-25 \% / \mathrm{Fe}-5 \%$ and $\mathrm{RHC} / \mathrm{K}_{2} \mathrm{O}-30 \% / \mathrm{Fe}-5 \%$ likely showed the same result of biodiesel production. Generally, a higher concentration of K-loading is inessential as the best catalyst because the very high basicity characteristic tends to cause difficulty for fatty acid methyl ester (FAME) molecule to desorb after the reaction and vice versa for lower loading concentration in which the reaction itself will not initiate due to low basicity for adsorption of reactant molecules [66]. According to the attained results, the biodiesel yields increased as the catalyst loading was increased from 1 to $4 \mathrm{wt} \%$ respectively. Meanwhile, further increase of catalyst loading up to $8 \mathrm{wt} \%$ showed the drop of biodiesel yield due to agglomeration of catalyst particles, causing the reactant mixture to become, viscous which led to poor blending between the catalyst and reactants [23]. The result exhibited that 4 wt $\%$ of $\mathrm{RHC} / \mathrm{K}_{2} \mathrm{O}-20 \% / \mathrm{Fe}-5 \%$ was the optimal amount of catalyst loading for the reaction. 


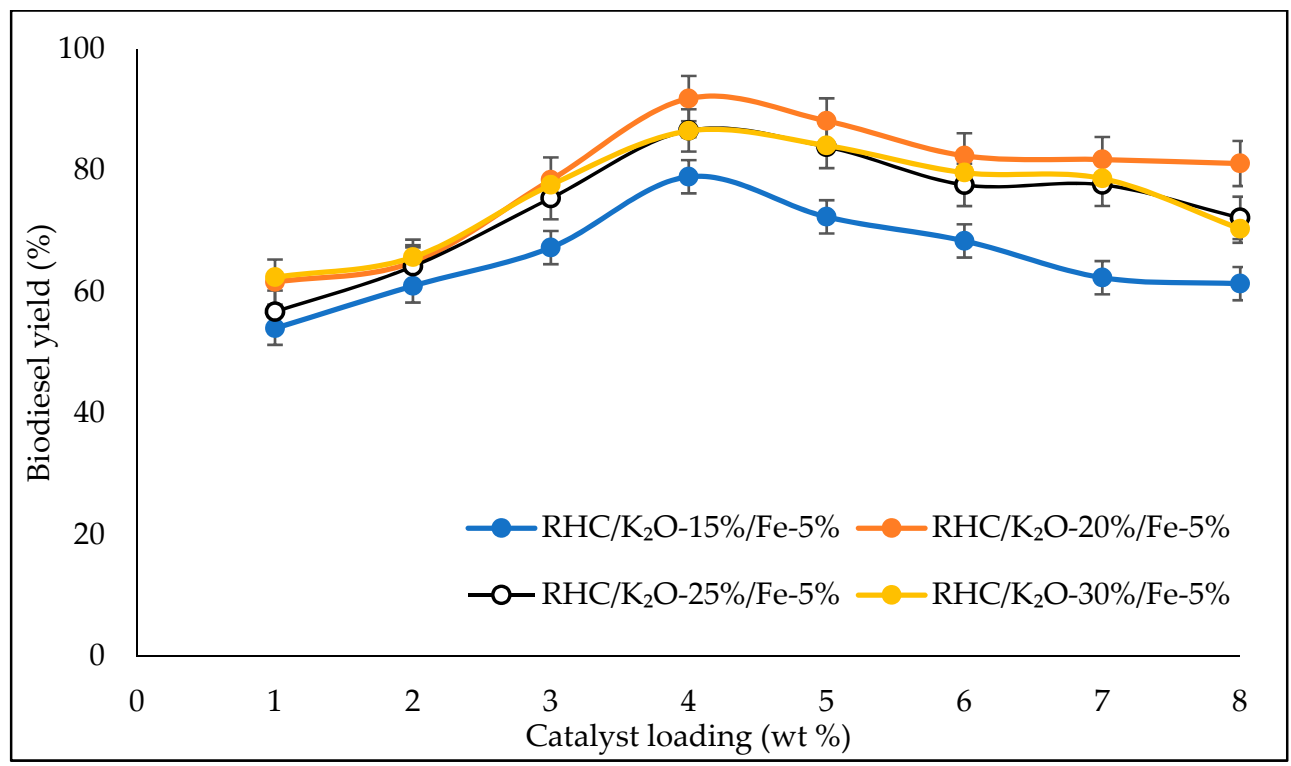

Figure 6. Screening of supermagnetic nano-bifunctional catalyst based on the catalyst loading for transesterification reaction with methanol: oil; 10:1, at temperature $65^{\circ} \mathrm{C}$ for $4 \mathrm{~h}$.

\subsubsection{Effects of Methanol to Oil Molar Ratio}

Transesterification reaction requires methanol as the basic reactant to react with UCO, and the molar ratio of methanol to oil is one of the significant parameters which influence the conversion of triglycerides to fatty acid methyl ester (FAME). Basically, the transesterification reaction is an equilibrium reaction where the conversion of biodiesel could be raised by applying the excessive methanol to force the equilibrium to the product formation $[67,68]$. The relationship between methanol to oil molar ratio is shown in Figure 7a. Based on the experimental data, the conversion rate increased from $71.4 \%$ to $92.5 \%$ as the methanol to oil molar ratio increased from $6: 1$ to $12: 1$, and the best result of the molar ratio was 12:1. Meanwhile, biodiesel production decreased to $70.44 \%$ with an additional increase of the molar ratio of methanol to oil to 27:1. The excesses amount of oil to methanol ratio enables the contact among reagents and catalyst to fasten the reaction, whereas, the surplus methanol give negative impact on transesterification because it could diminish the catalyst concentration and UCO that hinders the triglyceride molecules to the active sites, which leads to the reduction of biodiesel yield [69]. Also, the transesterification of excess methanol to oil ratio will favor glycerolysis reaction, which interferes with the phase separation of glycerol due to an increase in glycerol solubility in methanol, which drives the equilibrium to the reactants and reduces the ester yield [29,67]. As per the above results, the 12:1 methanol to oil molar ratio was selected as the optimum ratio. 

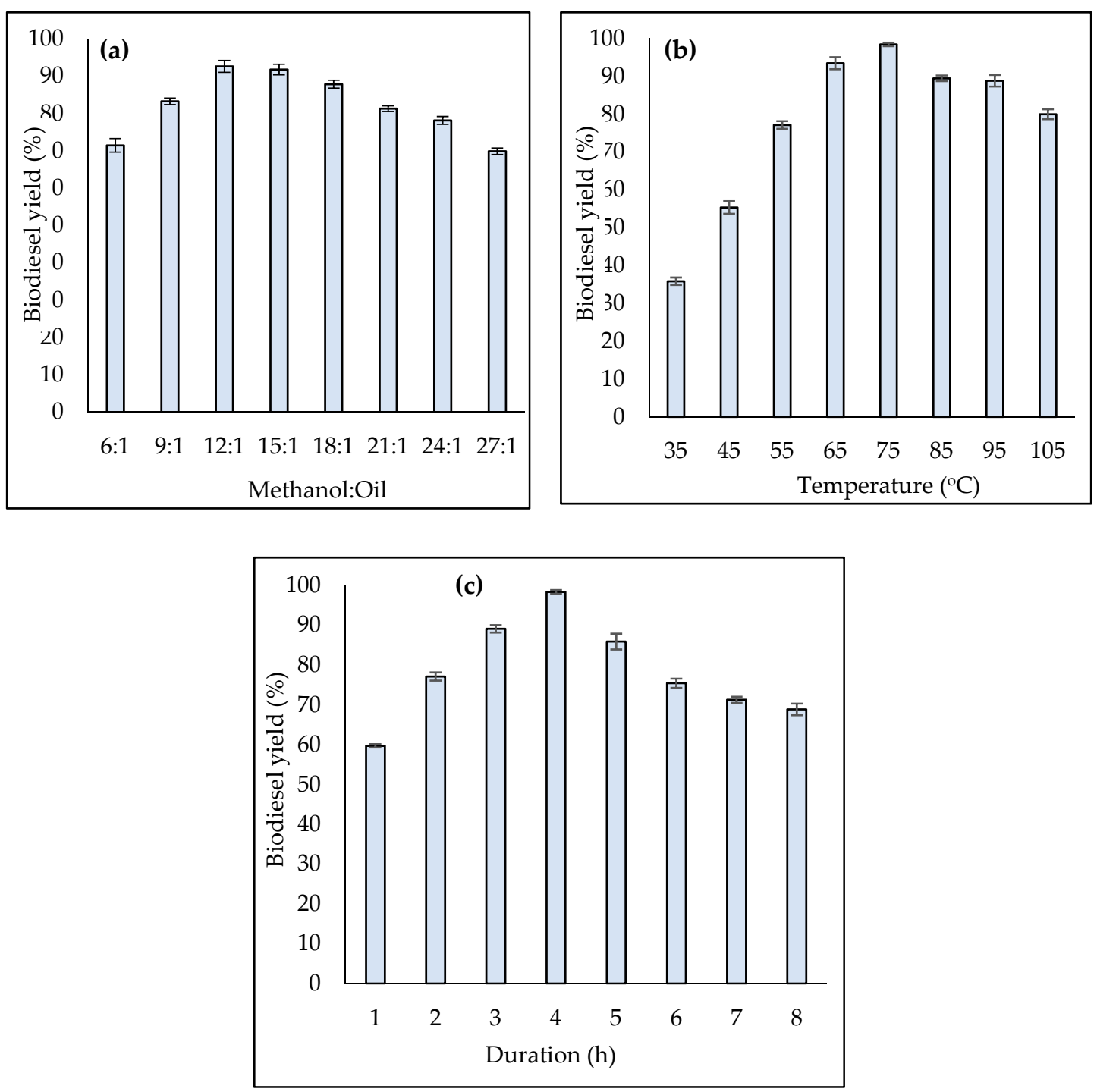

Figure 7. (a) Effect of methanol to oil molar ratio on the biodiesel yield using $\mathrm{RHC} / \mathrm{K}_{2} \mathrm{O}-20 \% / \mathrm{Fe}-5 \%$ catalyst (b) Effect of temperature on the biodiesel yield using $\mathrm{RHC} / \mathrm{K}_{2} \mathrm{O}-20 \% / \mathrm{Fe}-5 \%$ (c) Effect of reaction time on the biodiesel yield using $\mathrm{RHC} / \mathrm{K}_{2} \mathrm{O}-20 \% / \mathrm{Fe}-5 \%$.

\subsubsection{Effects of Reaction Temperature}

Transesterification was performed to determine the optimum reaction temperature by changing temperature range from $35{ }^{\circ} \mathrm{C}$ to $105^{\circ} \mathrm{C}$ through the increment of $10^{\circ} \mathrm{C}$. The reaction rate can be improved exponentially by the increase of reaction temperature. Also, the reactant was more mixable which permits higher reaction rate [70]. Figure $7 \mathrm{~b}$ displays the effect of reaction temperature on the biodiesel yield. At temperature between $35{ }^{\circ} \mathrm{C}$ to $55^{\circ} \mathrm{C}$, the conversion yield of methyl ester was below $60 \%$ due to the limitations of mass transfer and reactant solubility while at higher temperature, the reactants gained enough kinetic energy, which speeds up the mass transfer rate among the oil, methanol and catalyst phases, which results in the maximum conversion, $98.6 \%$ at $75^{\circ} \mathrm{C}$. However, when the reaction temperature proceeded above $75^{\circ} \mathrm{C}$, a slight loss in activity was observed because of high vaporization of the methanol that remained in the vapor phase. In addition, at a higher temperature reaction, the polarity of methanol decreased and resulted in a low concentration of methoxide species in reaction mixture $[29,66,71]$. 


\subsubsection{Effects of Reaction Duration}

The optimized reaction time can play a vital role in producing economical biodiesel. The result shown in Figure 7c indicated that the conversion of FAME improved significantly as the reaction time was amplified, and a maximum conversion was obtained at an optimum reaction time of $4 \mathrm{~h}$. The low biodiesel yield at lower conversion time intervals was reported due to insufficient conversion of FAME while the transesterification decreased as the reaction extended more than $4 \mathrm{~h}$ due to the formation of soap [23,72]. Besides, the decreasing of biodiesel yield beyond the optimized duration can be deduced to the reversible nature of the conversion reaction of oil to biodiesel [73].

\subsection{Reusability and Study of Deactivation of Supramagnetic $\mathrm{RHC} / \mathrm{K}_{2} \mathrm{O}-20 \% / \mathrm{Fe}-5 \%$ Nano-Bifunctional Catalyst}

The recovery and reusability of heterogeneous catalysts are one of the significant factors that influence the economics of biodiesel productions. The regenerated supramagnetic $\mathrm{RHC} / \mathrm{K}_{2} \mathrm{O}-20 \% / \mathrm{Fe}-5 \%$ nano-bifunctional catalyst was evaluated at the optimal reaction conditions for reusability study, as presented in Figure 8a. It was noticed that after a second cycle, the biodiesel yield dropped from $98.4 \%$ to $91.3 \%$. Whereas, in the third cycle, the biodiesel yield was reduced to $88.7 \%$, and it was observed that the catalytic activity considerably reduced to $44.1 \%$ after the sixth cycle. Thus, the produced catalyst can be used for at least five cycles with significant yield. The reduction in the biodiesel yield was probably due to the deposition of remaining organic impurities or product intermediate (such as oil, biodiesel, glycerol, and FFAs) on the active site of the nano-magnetic RHC/ $\mathrm{K}_{2} \mathrm{O}-20 \% / \mathrm{Fe}-5 \%$ catalyst which hindered the reagents' access [74]. Contamination by moisture and carbon dioxide in the air during the separation process by the external magnetic field also contributed to the deactivation of the nano-magnetic catalyst [18].

Further studies of catalyst deactivation were conducted using $\mathrm{N}_{2}$ adsorption-desorption, TPD- $\mathrm{CO}_{2} / \mathrm{NH}_{3}, \mathrm{XRD}$, and VSM characterization for fresh $\mathrm{RHC} / \mathrm{K}_{2} \mathrm{O}-20 \% / \mathrm{Fe}-5 \%$ and spent $\mathrm{RHC} / \mathrm{K}_{2} \mathrm{O}-20 \% / \mathrm{Fe}-5 \%$ (6th cycle). The specific surface area and pore volume of spent catalyst dropped from $57.89 \mathrm{~m}^{2} \mathrm{~g}^{-1}$ to $2.78 \mathrm{~m}^{2} \mathrm{~g}^{-1}$ and $0.0588 \mathrm{~cm}^{3} \mathrm{~g}^{-1}$ to $0.0102 \mathrm{~cm}^{3} \mathrm{~g}^{-1}$ respectively, probably due to the attachment of large molecules from transesterification products such as FAME, glycerol and unreacted oil which caused less interaction for adsorption-desorption between nitrogen gas and catalyst surface. The basicity and acidity concentration of the catalyst were related to its surface area, where low adsorption of probe gases $\left(\mathrm{CO}_{2} / \mathrm{NH}_{3}\right)$ showed lower basicity and acidity strength compared to the fresh catalyst, as stated in Table 2. The XRD pattern (Figure $8 b$ ) of the spent nano-magnetic catalyst predicted no noticeable structural variation as compared to the fresh catalyst, whereas the intensity of few diffraction peaks of the spent supermagnetic nano-bifunctional catalyst was lower than the fresh nano-magnetic catalyst after six consecutive cycles. Also, the crystal structure of the reused catalyst was altered. The masking of the impurities on the active site of supermagnetic nano-bifunctional spent catalyst did affect the magnetization strength, which reduced to $2.76 \mathrm{emug}^{-1}$ as shown in Figure 8c. Instead of deactivation of nano-magnetic catalyst by a poisoning mechanism through the attachment of large molecules [18], the repeating process of catalyst reactivation by calcining at high temperature of $550^{\circ} \mathrm{C}$ or known as thermal degradation might cause the mesoporous catalyst active site to collapse and result in the decrease in surface area and pore volume which would thus reduce the catalytic activity [75].

Table 2. Textural properties and total $\mathrm{CO}_{2}, \mathrm{NH}_{3}$ desorption of fresh nano-magnetic $\mathrm{RHC} / \mathrm{K}_{2} \mathrm{O}-20 \% / \mathrm{Fe}-5 \%$ and spent nano-magnetic $\mathrm{RHC} / \mathrm{K}_{2} \mathrm{O}-20 \% / \mathrm{Fe}-5 \%$.

\begin{tabular}{cccccc}
\hline Catalyst & $\mathbf{S}_{\mathbf{B E T}}\left(\mathbf{m}^{\mathbf{2}} \mathbf{g}^{-\mathbf{1}}\right)$ & $\mathbf{D}_{\mathbf{p}}(\mathbf{n m})$ & $\mathbf{V}_{\mathbf{p}}\left(\mathbf{c m}^{\mathbf{3}} \mathbf{g}^{-\mathbf{1}}\right)$ & $\begin{array}{c}\text { Total Basicity } \\
\left(\mathbf{m m o l g}^{-\mathbf{~}}\right)\end{array}$ & $\begin{array}{c}\text { Total Acidity } \\
\left(\mathbf{m m o l g}^{-\mathbf{1}}\right)\end{array}$ \\
\hline $\mathrm{RHC} / \mathrm{K}_{2} \mathrm{O}-20 \% / \mathrm{Fe}-5 \%$ & 57.89 & 4.70 & 0.0588 & 4.43 & 24.59 \\
$\begin{array}{c}\text { Spent } \\
\mathrm{RHC} / \mathrm{K}_{2} \mathrm{O}-20 \% / \mathrm{Fe}-5 \%\end{array}$ & 2.78 & 14.66 & 0.0102 & 0.53 & 6.47 \\
\hline
\end{tabular}



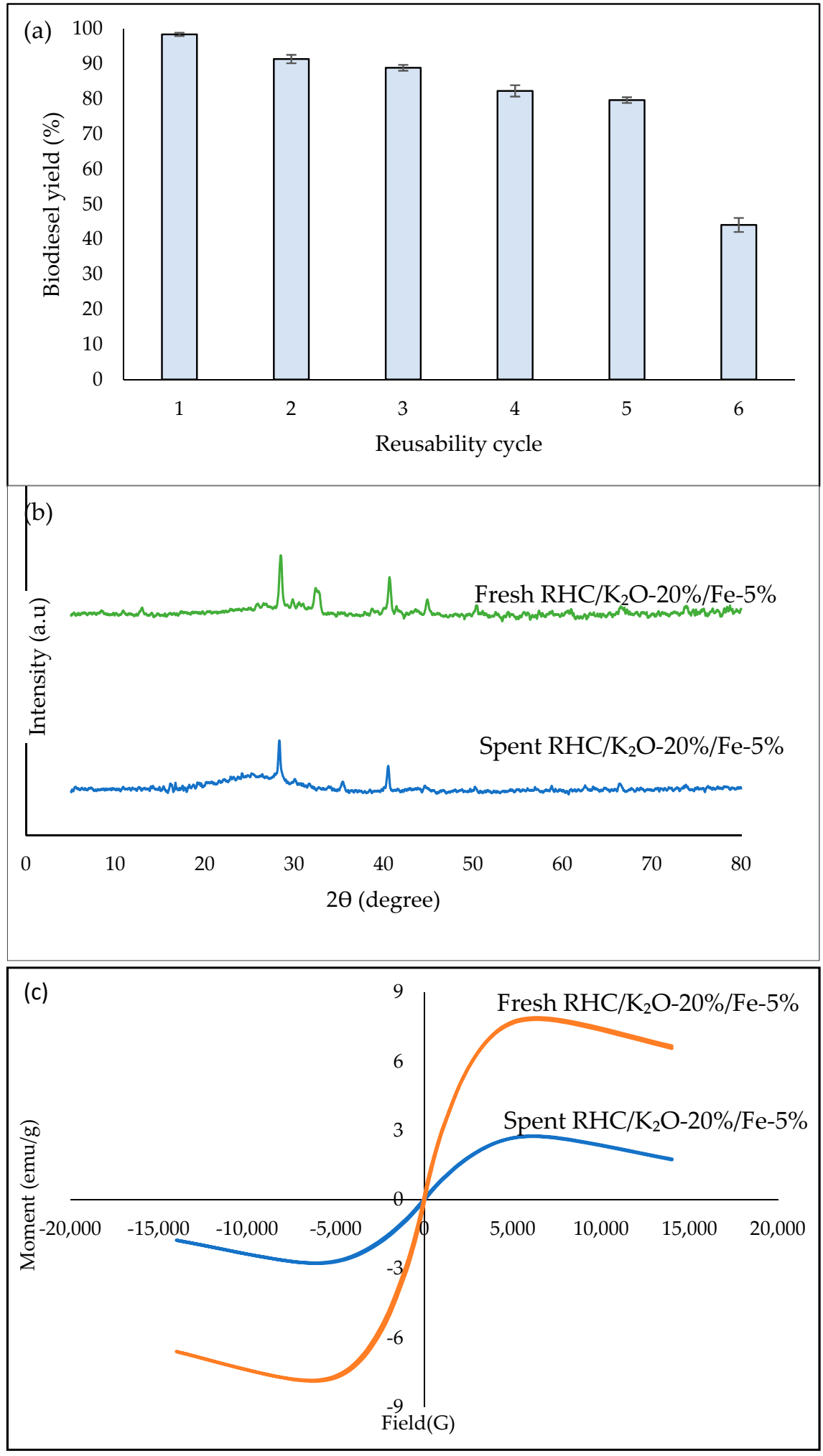

Figure 8. (a) Reusability of the $\mathrm{RHC} / \mathrm{K}_{2} \mathrm{O}-20 \% / \mathrm{Fe}-5 \%$ catalyst in biodiesel production (b) XRD pattern of fresh $\mathrm{RHC} / \mathrm{K}_{2} \mathrm{O}-20 \% / \mathrm{Fe}-5 \%$ and spent $\mathrm{RHC} / \mathrm{K}_{2} \mathrm{O}-20 \% / \mathrm{Fe}-5 \%$, (c) Magnetic strength (VSM).

\subsection{Comparative Study of Catalytic Activity with Literature Reported on Biochar Supported Catalysts}

The comparative study of catalytic activity in the transesterification reaction between nanomagnetic $\mathrm{RHC} / \mathrm{K}_{2} \mathrm{O}-20 \% / \mathrm{Fe}-5 \%$ catalyst and other reported biochar supported catalysts is listed in 
Table 3. The compiled data suggested that the as-synthesized $\mathrm{RHC} / \mathrm{K}_{2} \mathrm{O}-20 \% / \mathrm{Fe}-5 \%$ catalyst depicted that catalyst produced in the present study was comparable in terms of catalytic activity to previously reported biochar catalysts in the literature. It was noted that the $\mathrm{RHC} / \mathrm{K} 2 \mathrm{O}-20 \% / \mathrm{Fe}-5 \%$ catalyst was an effective and efficient supermagnetic nano-bifunctional catalyst for the transesterification of UCO.

Table 3. Comparison of $\mathrm{RHC} / \mathrm{K}_{2} \mathrm{O}-20 \% / \mathrm{Fe}-5 \%$ catalyst activity with biochar-supported catalysts.

\begin{tabular}{cccccccc}
\hline \multirow{2}{*}{ Catalyst } & Support & \multicolumn{5}{c}{ Reaction Condition } & \multicolumn{2}{c}{ FAME } \\
\cline { 2 - 8 } & $\begin{array}{c}\text { Catalyst } \\
\text { Loading (wt \%) }\end{array}$ & $\begin{array}{c}\text { Duration } \\
\text { (h) }\end{array}$ & $\begin{array}{c}\text { Molar } \\
\text { Ratio }\end{array}$ & $\begin{array}{c}\text { Temperature } \\
\left({ }^{\circ} \mathbf{C}\right)\end{array}$ & Yield (\%) \\
\hline $\begin{array}{c}\mathrm{CTPAC}(\mathrm{K}, \mathrm{P}, \\
\mathrm{CaMg})\end{array}$ & $\begin{array}{c}\text { Tucumã } \\
\text { peels }\end{array}$ & 1 & 4 & $15: 1$ & 80 & 97.3 & {$[41]$} \\
\hline $\mathrm{K} / \mathrm{BC}-\mathrm{Fe}_{2} \mathrm{O}_{3}$ & $\begin{array}{c}\text { Bamboo } \\
\text { charcoal }\end{array}$ & 2.5 & 1 & $8: 1$ & 60 & 98.0 & {$[19]$} \\
\hline $\mathrm{Ca}_{2} \mathrm{Fe}_{2} \mathrm{O}_{5}-\mathrm{CNH}$ & $\begin{array}{c}\text { Carbon } \\
\text { nanohorn }\end{array}$ & - & 3 & - & - & 97.0 & {$[38]$} \\
\hline $25 \mathrm{~K} / \mathrm{AP}-600$ & Pomelo peel & 6 & 2.5 & $8: 1$ & 65 & 98.0 & {$[40]$} \\
\hline $\begin{array}{l}\mathrm{RHC} / \mathrm{K}_{2} \mathrm{O}- \\
20 \% / \mathrm{Fe}-5 \%\end{array}$ & $\begin{array}{c}\text { Rice husk } \\
\text { char }\end{array}$ & 4 & 4 & $12: 1$ & 75 & 98.6 & This work \\
\hline
\end{tabular}

2.5. Biodiesel Confirmation Using ${ }^{1} H$-Nuclear Magnetic Resonance $\left({ }^{1} H-N M R\right)$ and Fourier-Transform Infrared Spectroscopy (FTIR)

The confirmation of biodiesel production was characterized using ${ }^{1} \mathrm{H}-\mathrm{NMR}$ and FTIR spectroscopy and was compared with used cooking oil. The ${ }^{1} \mathrm{H}-\mathrm{NMR}$ spectrum of biodiesel and UCO is presented in Figure S2a,b. The typical peak of deuterated chloroform $\left(\mathrm{CDCl}_{3}\right)$ was detected at $7.29 \mathrm{ppm}$ [72]. The spectra of biodiesel had a characteristic peak of singlet methoxy proton at $3.61 \mathrm{ppm}$, and a triplet of an $\alpha$-methylene group of esters approximately found at $2.24 \mathrm{ppm} \mathrm{[76].} \mathrm{These} \mathrm{two} \mathrm{peaks} \mathrm{were}$ not observed in UCO, therefore validating the conversion of triglyceride into respective fatty acid methyl ester. The other signals of multiplet formed at 5.26 ppm-5.34 ppm were identified as olefinic hydrogen [77]. A multiplet peak signal at $0.83 \mathrm{ppm}-0.86 \mathrm{ppm}$ was recognized as terminal methyl protons. A multiplet signal of methylene protons of carbon chain was located at $1.22 \mathrm{ppm}-1.34 \mathrm{pm}$, and the signal of $\beta$-carbonyl methylene protons was observed at $1.56 \mathrm{ppm}-1.60 \mathrm{ppm}[63,78,79]$.

The functional groups and vibration bands of the synthesized biodiesel and UCO were identified in which both FTIR spectra of biodiesel and UCO samples were nearly alike but significantly different in the methyl ester functional peak observed as shown in Figure S3. The absorption band of $=\mathrm{C}-\mathrm{H}$ stretching vibration of UCO and biodiesel samples was observed at $3005.47 \mathrm{~cm}^{-1}$. Carbon-carbon single bonds of asymmetric and symmetric, $-\mathrm{C}-\mathrm{H}$ stretching vibration were located at $2921.14 \mathrm{~cm}^{-1}$ and $2852.35 \mathrm{~cm}^{-1}$. The absorption peaks at $1742.78 \mathrm{~cm}^{-1}, 1641.15 \mathrm{~cm}^{-1}$ belonged to the stretching vibration of carbonyl $-\mathrm{C}=\mathrm{O}$ functional group and olefin carbon-carbon double bond $-\mathrm{C}=\mathrm{C}-$, respectively. $1460.77 \mathrm{~cm}^{-1}$ peak corresponded to $-\mathrm{C}-\mathrm{H}$, alkane bending. Stretching vibrations of the $\mathrm{C}-\mathrm{O}-\mathrm{C}$ ester group were observed at $1158.64 \mathrm{~cm}^{-1}$ and $721.20 \mathrm{~cm}^{-1}$, indicating that $\mathrm{C}-\mathrm{C}-\mathrm{H}$ was out of the plane of stretching vibration. The presence of two extra peaks in the biodiesel sample at $1437.64 \mathrm{~cm}^{-1}$ and $1195.76 \mathrm{~cm}^{-1}$ were determined as the asymmetric stretching vibration of methyl carbon-hydrogen bond and stretching vibration of $-\mathrm{O}-\mathrm{CH}_{3}$ group of mono-, di-, and triglyceride to indicate the formation of biodiesel $[62,80,81]$.

\section{Materials and Method}

\subsection{Materials}

The rice husk was obtained from PLS Marketing (M) SHD BHD and used cooking oil (UCO) was procured from a local restaurant in Serdang, Selangor. All the materials, i.e., potassium hydroxide ( $\mathrm{KOH}$; J.T Barker, St. Phillipsburg, NJ, USA, $86.0 \%)$, potassium carbonate $\left(\mathrm{K}_{2} \mathrm{CO}_{3}\right.$; R\&M Chemicals, 
Subang, SGR, MY, 99.5\%), iron (III) chloride hexahydrate $\left(\mathrm{FeCl}_{3} .6 \mathrm{H}_{2} \mathrm{O}\right.$; Friedmann Schmidt, Kajang, SGR, MY, 98.0\%) and methanol $\left(\mathrm{CH}_{3} \mathrm{OH}\right.$; Systerm, Shah Alam, SGR, MY, 99.8\%) were analytical grade and used without further purification.

\subsection{Synthesis of Rice Husk Char}

The rice husk $(\mathrm{RH})$ was washed with distilled water $\left(\mathrm{H}_{2} \mathrm{O}\right)$ to remove rice residue, clay particles, and sieved it. After multiple washing with distilled water, the $\mathrm{RH}$ was filtered and oven-dried $\left(105^{\circ} \mathrm{C}\right)$ until it achieved constant weight. The rice husk char (RHC) was prepared by carbonization at $450{ }^{\circ} \mathrm{C}$ for $3 \mathrm{~h}$ under nitrogen $\left(\mathrm{N}_{2}\right)$ flow. The RHC was treated with $1 \mathrm{M}$ potassium hydroxide to eliminate traces of minerals and enhance the pore size of the char. The treated RHC was washed with hot distilled water until $\mathrm{pH} 7$ and dried in the oven at $105^{\circ} \mathrm{C}[31,82]$.

\subsection{Preparation of Nano-Magnetic $\mathrm{RHC} / \mathrm{K}_{2} \mathrm{O} / \mathrm{Fe}$ Catalyst}

A series of $\mathrm{RHC} / \mathrm{K}_{2} \mathrm{O} / \mathrm{Fe}$ catalysts with varying potassium oxide loadings ( $\mathrm{K}_{2} \mathrm{O}: 15,2025$ and $30 \mathrm{wt} \%$ ) with $5 \%$ and $10 \%$ iron (III) oxide were prepared by wet impregnation method of RHC supported with aqueous solution of potassium carbonate $\left(\mathrm{K}_{2} \mathrm{CO}_{3}\right)$ and iron (III) chloride hexahydrate $\left(\mathrm{FeCl}_{3} \cdot 6 \mathrm{H}_{2} \mathrm{O}\right)$. Both solutions of $\mathrm{K}_{2} \mathrm{CO}_{3}$ and $\mathrm{FeCl}_{3} \cdot 6 \mathrm{H}_{2} \mathrm{O}$ were dropped simultaneously into wet $\mathrm{RHC}$ and mixed vigorously for $6 \mathrm{~h}$. The mixture was filtered and dried in the oven overnight at $70{ }^{\circ} \mathrm{C}$. The dried solid base catalyst was carbonized in the furnace at $700{ }^{\circ} \mathrm{C}$ for $3 \mathrm{~h}$ with a heating rate of $3{ }^{\circ} \mathrm{C} \min ^{-1}[83]$.

\subsection{Characterization of $\mathrm{RHC} / \mathrm{K}_{2} \mathrm{O} / \mathrm{Fe}$ Catalysts}

The crystallinity behavior of synthesized supermagnetic nano-bifunctional catalysts was characterized by using X-ray diffraction XRD-6000, (Shimadzu, Kyoto, JPN) coupled with Cu-K $\alpha$ radiation $(30.0 \mathrm{kV}, 30.0 \mathrm{~mA})$ at a scanning rate of $2^{\circ} \mathrm{min}^{-1}$ and a scanning range of $2^{\circ}$ to $80^{\circ}$ [83].

Temperature programmed desorption method of carbon dioxide and ammonia gas $\left(\mathrm{CO}_{2}-\mathrm{TPD} / \mathrm{NH}_{3}-\mathrm{TPD}\right)$ as probe gas were used to analyze the basicity and acidity strength of supermagnetic nano-bifunctional catalysts derived from rice husk using TPD/R/O/1100 series (Thermo Finnigan, Kyoto, JPN) apparatus coupled with thermal conductivity detector (TCD). The RHC/ $\mathrm{K}_{2} \mathrm{O} / \mathrm{Fe}$ catalysts samples were pretreated under $\mathrm{N}_{2}$ gas flow for $1 \mathrm{~h}$ at $150{ }^{\circ} \mathrm{C}$, during the acid site distribution analysis. The absorption of $\mathrm{NH}_{3}$ was carried out under the flow of $\mathrm{NH}_{3}$ stream for $1 \mathrm{~h}$, and then the $\mathrm{RH}$, $\mathrm{RHC}$, and $\mathrm{RHC} / \mathrm{K}_{2} \mathrm{O} / \mathrm{Fe}$ catalysts were again flowed with $\mathrm{N}_{2}$ gas for $45 \mathrm{~min}$ to remove excess $\mathrm{NH}_{3}$ gas prior to analysis. Also, the basicity of $\mathrm{RH}, \mathrm{RHC}$, and $\mathrm{RHC} / \mathrm{K}_{2} \mathrm{O} / \mathrm{Fe}$ catalysts sample were subjected to only a single pretreatment under the flow of $\mathrm{CO}_{2}$ gas. The chemisorption of $\mathrm{CO}_{2}$ and $\mathrm{NH}_{3}$ was carried out by $\mathrm{CO}_{2}$ and $\mathrm{NH}_{3}$ gas at a flow rate of $20 \mathrm{~mL} \mathrm{~min}^{-1}$ for $1 \mathrm{~h}$, respectively. The additional $\mathrm{CO}_{2}$ or $\mathrm{NH}_{3}$ was then flushed with Helium (He) gas for $30 \mathrm{~min}$ at a flow rate of $30 \mathrm{~mL} \mathrm{~min}^{-1}$. The desorption of $\mathrm{CO}_{2}$ and $\mathrm{NH}_{3}$ proceeded with the flow of He gas as carrier gas with a ramp of $10^{\circ} \mathrm{C} \mathrm{min}^{-1}$ from $50^{\circ} \mathrm{C}$ to $950^{\circ} \mathrm{C}$ and held for $30 \mathrm{~min}$. The amounts of desorbed $\mathrm{CO}_{2}$ and $\mathrm{NH}_{3}$ were measured and noted [84].

The textural properties such as surface area, pore volume and pore size distribution of RH, RHC, and $\mathrm{RHC} / \mathrm{K}_{2} \mathrm{O} / \mathrm{Fe}$ catalysts samples were performed by using Brunauer-Emmer-Teller (BET) and Barrett-Joyner-Halenda (BJH) techniques from the desorption loop method with a Micromeritics ASAP-2020 (Micromeritics Instrument, Norcross, GA, USA). The catalyst sample was degassed at $120{ }^{\circ} \mathrm{C}$ to remove adsorbed contaminants and water vapor on the surface of the catalyst [85].

The active functional group on the surface of raw $\mathrm{RH}, \mathrm{RHC}$, and $\mathrm{RHC} / \mathrm{K}_{2} \mathrm{O}-20 \% / \mathrm{Fe}-5 \%$ were characterized by Fourier transform infrared (FTIR) spectroscopy in the range $400-4000 \mathrm{~cm}^{-1}$ using Thermo Nicolet-7000.(Thermo Fisher Scientific, Waltham, MA, USA) Potassium bromide (KBr, Merck, Darmstadt, DE, 99.0\%) was utilized as the sample matrix for determining FTIR spectra with a spectral resolution of $4 \mathrm{~cm}^{-1}$ [31].

Thermogravimetric analyzer (TGA-DTA) was used to evaluate the thermal decomposition rice husk $(\mathrm{RH})$, rice husk char ( $\mathrm{RHC}$ ) and $\mathrm{RHC} / \mathrm{K}_{2} \mathrm{O}-20 \% / \mathrm{Fe}-5 \%$ catalyst using TG-50 Mettler instrument 
(Mettler Toledo, Shah Alam, SGR, MY) under airflow of $50 \mathrm{~mL} \mathrm{~mol}^{-1}$ with a heating rate of $10{ }^{\circ} \mathrm{C} \mathrm{min}-1$ from room temperature to $1000{ }^{\circ} \mathrm{C}$ [19].

The morphologies of $\mathrm{RH}, \mathrm{RHC}$, and nano-magnetic RHC catalysts were determined with field-emission scanning electron microscopy (FESEM, Novananosem-230). The sample was sputtercoated with $7 \mathrm{~nm}$ gold $(\mathrm{Au})$ to enhance the conductivity for better image resolution [86].

The magnetization of supermagnetic nano-bifunctional RHC/ $\mathrm{K}_{2} \mathrm{O}-20 \% / \mathrm{Fe}-5 \%$ was measured using a vibrating sample magnetometer (VSM, Lake Shore 7404 series, Lake Shore Cryotronics, Westerville, $\mathrm{OH}, \mathrm{USA}$ ). The VSM was calibrated with a pure nickel sphere with a standard value of $6.95 \mathrm{emu} \mathrm{g}^{-1}$. A pinch of the pre-weighed magnetic catalyst was sandwiched with clear duck tapes and attached on the surface of the VSM sample tail. The sample tail was inserted into a sample chamber, and the VSM was operated with 1.4 Tesla at room temperature.

\subsection{Catalytical Activity Reactions Via Transesterification}

Transesterification of biodiesel was carried out in $100 \mathrm{~mL}$ of 3-necked round-bottomed flask equipped with a water-cooled condenser and mechanical stirring under atmospheric pressure. Approximately $10 \mathrm{~g}$ of used cooking oil (UCO), the desired amount of methanol, and $\mathrm{RHC} / \mathrm{K}_{2} \mathrm{O} / \mathrm{Fe}$ catalyst was weighed and placed in the round-bottomed flask. The reaction sample was heated at $65^{\circ} \mathrm{C}$ for $4 \mathrm{~h}$ and stirred by using the magnetic stirrer. After transesterification, the magnetic base catalyst was removed by using an external magnetic bar, and two phases of products were formed, which consisted of glycerol and biodiesel at the bottom and top layers, respectively. The excess methanol was removed by using a rotary evaporator. The unreacted oil from the synthesized biodiesel was removed by washing with hot distilled water, and the excess water was dried by adding ammonium sulfate $\left(\left(\mathrm{NH}_{4}\right)_{2} \mathrm{SO}_{4}\right.$, Merck, Darmstadt, DE, 99.0\%) based on the weight of oil. Next, the purified biodiesel was analyzed by gas chromatography, and methyl heptadecanoate was used as the internal standard with hexane (Merck, Darmstadt, DE, $98.5 \%$ ) as a solvent. The diverse parametric conditions for the transesterification of UCO allowed to ensure the achievement of an optimized reaction [87].

\subsection{Biodiesel Analysis}

The qualitative properties of purified methyl ester were examined using gas chromatography (GC) with flame ionization detector (FID) detector and a polar BPX-70 capillary column (60 m length; $0.25 \mathrm{~mm}$ ID; $0.25 \mu \mathrm{m}$ capillary diameter) (Trajan Scientific, Ringwood, VIC, AUS). The $n$-hexane was used as GC solvent; whereas, methyl heptadecanoate was applied as an internal standard. The reference standards were prepared as; $500 \mathrm{ppm}$ of each standard methyl palmitate, methyl oleate, methyl myristate, methyl stearate, and methyl linoleate. Briefly, $1 \mu \mathrm{m}$ of prepared biodiesel sample was injected into the injection port; the GC oven temperature was fixed to increase from $100{ }^{\circ} \mathrm{C}-250{ }^{\circ} \mathrm{C}$ with $10{ }^{\circ} \mathrm{C} \mathrm{min}^{-1}$ of the temperature ramp rate. The FAME yield (\%) was measured using the formula stated below [11]:

$$
\text { FAME yield }(\%)=\frac{\Sigma \mathrm{A}-\mathrm{A}_{m e h}}{\mathrm{~A}_{m e h}} \times \frac{\mathrm{C}_{m e h} \times \mathrm{V}_{m e h}}{\mathrm{Wt}} \times 100
$$

where; $\sum \mathrm{A}\left(\mathrm{mm}^{2}\right)=$ Total area of peaks; $\mathrm{A}_{\text {meh }}\left(\mathrm{mm}^{2}\right)=$ Peak area of methyl heptadecanoate; $\mathrm{C}_{\text {meh }}(\mathrm{ppm})$ $=$ Concentration of methyl heptadecanoate; $\mathrm{V}_{\text {meh }}(\mathrm{mL})=$ Volume of methyl heptadecanoate; $\mathrm{Wt}(\mathrm{g})=$ Weight of the product.

In addition, the confirmation of biodiesel production was characterized by using ${ }^{1} \mathrm{H}-\mathrm{NMR}$ and FTIR spectroscopy and was compared with used cooking oil. ${ }^{1} \mathrm{H}-\mathrm{NMR}$ spectra were recorded on Bruker AVANCE-500 MHz instrument (Bruker Corporation, Billerica, MA, USA) and the deuterated chloroform $\left(\mathrm{CDCl}_{3}\right.$, Merck, Darmstadt, DE, 99.96 \%and tetramethylsilane (TMS) were used as a solvent and internal standard, respectively. The FTIR spectra was recorded using Thermo Nicolet-7000 Spectrometer equipped with attenuated total reflectance (ATR) sampling accessory. A Diamond-ATR accessory with a removable ZnSe crystal was mounted on the sample compartment of the spectrometers. The liquid sample of UCO and biodiesel were filled onto the trough plate, respectively, and the cover 
was placed over the trough plate. The infrared spectra were scanned from $400-4000 \mathrm{~cm}^{-1}$ with a spectral resolution of $4 \mathrm{~cm}^{-1}$.

\subsection{Catalyst Regeneration and Spent Catalyst Characterisation}

The spent nano-magnetic catalyst from the synthesized biodiesel was collected by using the external magnetic field and washed with acetone and $n$-hexane to remove the impurities trapped on the catalyst surface. Then, the washed catalyst was dried in the oven for $6 \mathrm{~h}$ at $80^{\circ} \mathrm{C}$ and was reactivated at $550^{\circ} \mathrm{C}$ for $2 \mathrm{~h}$ in a furnace with nitrogen flow. The recovered nano-magnetic catalyst was reused at optimum conditions to study the reusability of the catalyst and characterization of spent nano-bifunctional supermagnetic catalyst using BET, TPD, XRD, and VSM were performed.

\section{Conclusions}

The super-magnetic nano-bifunctional $\mathrm{RHC} / \mathrm{K}_{2} \mathrm{O} / \mathrm{Fe}$ catalyst was successfully synthesized for the transesterification of UCO. The optimum super-magnetic nano-bifunctional $\mathrm{RHC} / \mathrm{K}_{2} \mathrm{O}-20 \% / \mathrm{Fe}-5 \%$ catalyst, possessed a specific surface area of $57.89 \mathrm{~m}^{2} \mathrm{~g}^{-1}$ and bifunctional properties for basic and acid densities of $4.43 \mathrm{mmolg}^{-1}$ and $24.55 \mathrm{mmolg}^{-1}$, respectively. The supermagnetic nano-bifunctional $\mathrm{RHC} / \mathrm{K}_{2} \mathrm{O}-20 \% / \mathrm{Fe}-5 \%$ catalyst, showed excellent catalytic activity and rigidity that can be reused until the fifth cycle. Its recoverability by using an external magnetic field has presented the most effective separation process due to its high magnetic property $\left(7.88 \mathrm{emug}^{-1}\right)$. The optimized conditions (amount of catalyst, $4 \mathrm{wt}$; methanol/oil molar ratio, 12:1; reaction time, $4 \mathrm{~h}$; reaction temperature, $75^{\circ} \mathrm{C}$ ) gave the highest biodiesel yield (98.6\%) through the conventional reflux system. A slight deactivation of the catalyst was found mainly due to non-selective poisoning in which the reactants deposited on the surface of active sites. Therefore, the supermagnetic nano-bifunctional $\mathrm{RHC} / \mathrm{K}_{2} \mathrm{O}-20 \% / \mathrm{Fe}-5 \%$ catalyst depicts to be an ideal magnetized catalyst as a replacement for conventional homogeneous and heterogeneous catalysts due to its potential for conversion of UCO to biodiesel, its effectiveness, and its practicability.

Supplementary Materials: The following are available online at http://www.mdpi.com/2073-4344/10/2/225/s1, Figure S1. (a) Nitrogen adsorption-desorption isotherms of the RH, RHC and RHC nano-magnetic catalysts, (b) Pore volume of the RH, RHC and RHC nano-magnetic catalysts, Figure S2. (a-b) ${ }^{1} \mathrm{H}-\mathrm{NMR}$ spectra of UCO and biodiesel, Figure S3. FTIR spectra of UCO and biodiesel

Author Contributions: The conceptualization of this journal article is from, B.H. and U.R.; the methodology was designed by B.H.; the writing - original draft was prepared by B.H.; and U.R. helped with the editing and supervision. M.L.I., Y.H.T.-Y., and I.A.N. reviewed the manuscript. All authors have read and agreed to the published version of the manuscript.

Funding: This project was financially supported by GP-IPS/2017/9580300 grant of Universiti Putra Malaysia. The authors acknowledge their gratitude to King Saud University (Riyadh, Saudi Arabia) for the funding of this research through Researchers Supporting Project number (RSP-2019/80).

Conflicts of Interest: The author declares no conflict of interest.

\section{References}

1. Jamil, F.; Al-Muhtaseb, A.H.; Al-Haj, L.; Al-Hinai, M.A.; Hellier, P.; Rashid, U. Optimization of oil extraction from waste "Date pits" for biodiesel production. Energy Convers. Manag. 2016, 117, 264-272. [CrossRef]

2. Seffati, K.; Honarvar, B.; Esmaeili, H.; Esfandiari, N. Enhanced biodiesel production from chicken fat using $\mathrm{CaO} / \mathrm{CuFe}_{2} \mathrm{O}_{4}$ nanocatalyst and its combination with diesel to improve fuel properties. Fuel 2019, 235, 1238-1244. [CrossRef]

3. Ibrahim, N.A.; Rashid, U.; Taufiq-Yap, Y.H.; Yaw, T.C.S.; Ismail, I. Synthesis of carbonaceous solid acid magnetic catalyst from empty fruit bunch for esterification of palm fatty acid distillate (PFAD). Energy Convers. Manag. 2019, 195, 480-491. [CrossRef]

4. Oladipo, A.S.; Ajayi, O.A.; Oladipo, A.A.; Azarmi, S.L.; Nurudeen, Y.; Atta, A.Y.; Ogunyemi, S.S. Magnetic recyclable eggshell-based mesoporous catalyst for biodiesel production from crude neem oil: Process 
optimization by central composite design and artificial neural network. C. R. Chim. 2018, 21, 684-695. [CrossRef]

5. Demirbas, A. Progress and recent trends in biodiesel fuels. Energy Convers. Manag. 2009, 50, 14-34. [CrossRef]

6. Rashid, U.; Rehman, H.A.; Hussain, I.; Ibrahim, M.; Haider, M.S. Muskmelon (Cucumis melo) seed oil: A potential non-food oil source for biodiesel production. Energy 2011, 36, 5632-5639. [CrossRef]

7. Mansir, N.; Teo, S.H.; Rabiu, I.; Taufiq-Yap, Y.H. Effective biodiesel synthesis from waste cooking oil and biomass residue solid green catalyst. Chem. Eng. J. 2018, 347, 137-144. [CrossRef]

8. Mahesh, S.E.; Ramanathan, A.; Begum, K.M.M.S.; Narayanan, A. Biodiesel production from waste cooking oil using KBr impregnated $\mathrm{CaO}$ as catalyst. Energy Convers. Manag. 2015, 91, 442-450. [CrossRef]

9. Sinha, D.; Murugavelh, S. Comparative studies on biodiesel production from Waste Cotton Cooking Oil using alkaline, calcined eggshell and pistachio shell catalyst. In Proceedings of the 2016 International Conference on Energy Efficient Technologies for Sustainability (ICEETS), Nagercoil, India, 7-8 April 2016; pp. 130-133.

10. Chung, Z.L.; Tan, Y.H.; Chan, Y.S.; Kansedo, J.; Mubarak, N.M.; Ghasemi, M.; Abdullah, M.O. Life cycle assessment of waste cooking oil for biodiesel production using waste chicken eggshell derived $\mathrm{CaO}$ as catalyst via transesterification. Biocatal. Agric. Biotechnol. 2019, 21, 101317. [CrossRef]

11. Wang, A.; Li, H.; Zhang, H.; Pan, H.; Yang, S. Efficient Catalytic Production of Biodiesel with Acid-Base Bifunctional Rod-Like Ca-B Oxides by the Sol-Gel Approach. Materials 2018, 12, 83. [CrossRef]

12. Soltani, S.; Rashid, U.; Nehdi, I.A.; Al-Resayes, S.I.; Al-Muhtaseb, A.H. Sulfonated mesoporous zinc aluminate catalyst for biodiesel production from high free fatty acid feedstock using microwave heating system. J. Taiwan Inst. Chem. Eng. 2017, 70, 219-228. [CrossRef]

13. Souza, R.D.; Vats, T.; Chattree, A.; Felix, P. Graphene supported magnetically separable solid acid catalyst for the single step conversion of waste cooking oil to biodiesel. Renew. Energy 2018, 126, 1064-1073. [CrossRef]

14. Tantirungrotechai, J.; Thepwatee, S.; Yoosuk, B. Biodiesel synthesis over Sr/MgO solid base catalyst. Fuel 2013, 106, 279-284. [CrossRef]

15. Rahmani Vahid, B.; Haghighi, M. Urea-nitrate combustion synthesis of $\mathrm{MgO} / \mathrm{MgAl}_{2} \mathrm{O}_{4}$ nanocatalyst used in biodiesel production from sunflower oil: Influence of fuel ratio on catalytic properties and performance. Energy Convers. Manag. 2016, 126, 362-372. [CrossRef]

16. Fan, M.; Wu, H.; Shi, M.; Zhang, P.; Jiang, P. Well-dispersive $\mathrm{K}_{2} \mathrm{O}-\mathrm{KCl}$ alkaline catalyst derived from waste banana peel for biodiesel synthesis. Green Energy Environ. 2019, 4, 322-327. [CrossRef]

17. Shahraki, H.; Entezari, M.H.; Goharshadi, E.K. Sono-synthesis of biodiesel from soybean oil by $\mathrm{KF} / \gamma-\mathrm{Al}_{2} \mathrm{O}_{3}$ as a nano-solid-base catalyst. Ultrason. Sonochem. 2015, 23, 266-274. [CrossRef]

18. Yatish, K.V.; Lalithamba, H.S.; Suresh, R.; Latha, H.K.E. Ochrocarpus longifolius assisted green synthesis of $\mathrm{CaTiO}_{3}$ nanoparticle for biodiesel production and its kinetic study. Renew. Energy 2020, 147, 310-321. [CrossRef]

19. Argyle, M.; Bartholomew, C. Heterogeneous Catalyst Deactivation and Regeneration: A Review. Catalysts 2015, 5, 145-269. [CrossRef]

20. Thushari, I.; Babel, S.; Samart, C. Biodiesel production in an autoclave reactor using waste palm oil and coconut coir husk derived catalyst. Renew. Energy 2019, 134, 125-134. [CrossRef]

21. Chellappan, S.; Aparna, K.; Chingakham, C.; Sajith, V.; Nair, V. Microwave assisted biodiesel production using a novel Brønsted acid catalyst based on nanomagnetic biocomposite. Fuel 2019, 246, 268-276. [CrossRef]

22. Rezayan, A.; Taghizadeh, M. Synthesis of magnetic mesoporous nanocrystalline $\mathrm{KOH} / \mathrm{ZSM}-5-\mathrm{Fe}_{3} \mathrm{O}_{4}$ for biodiesel production: Process optimization and kinetics study. Process Saf. Environ. Prot. 2018, 117, 711-721. [CrossRef]

23. Salimi, Z.; Hosseini, S.A. Study and optimization of conditions of biodiesel production from edible oils using $\mathrm{ZnO} / \mathrm{BiFeO}_{3}$ nano magnetic catalyst. Fuel 2019, 239, 1204-1212. [CrossRef]

24. Soltani, N.; Bahrami, A.; Pech-Canul, M.I.; González, L.A. Review on the physicochemical treatments of rice husk for production of advanced materials. Chem. Eng. J. 2015, 264, 899-935. [CrossRef]

25. Liu, D.; Zhang, W.; Lin, H.; Li, Y.; Lu, H.; Wang, Y. A green technology for the preparation of high capacitance rice husk-based activated carbon. J. Clean. Prod. 2016, 112, 1190-1198. [CrossRef]

26. Daffalla, S.B.; Mukhtar, H.; Shaharun, M.S. Properties of activated carbon prepared from rice husk with chemical activation. Int. J. Glob. Environ. Issues 2012, 12, 107-129. [CrossRef]

27. Shafini, M.S. A review on paddy residue based power generation: Energy, environment and economic perspective. Renew. Sustain. Energ. Rev. 2016, 59, 1089-1100. [CrossRef] 
28. Alvarez, J.; Lopez, G.; Amutio, M.; Bilbao, J.; Olazar, M. Upgrading the rice husk char obtained by flash pyrolysis for the production of amorphous silica and high quality activated carbon. Bioresour. Technol. 2014, 170, 132-137. [CrossRef]

29. Zhao, C.; Yang, L.; Xing, S.; Luo, W.; Wang, Z.; Lv, P. Biodiesel production by a highly effective renewable catalyst from pyrolytic rice husk. J. Clean. Prod. 2018, 199, 772-780. [CrossRef]

30. Fu, Y.; Shen, Y.; Zhang, Z.; Ge, X.; Chen, M. Activated bio-chars derived from rice husk via one- and two-step $\mathrm{KOH}$-catalyzed pyrolysis for phenol adsorption. Sci. Total Environ. 2019, 646, 1567-1577. [CrossRef]

31. Chen, G.; Shan, R.; Shi, J.; Yan, B. Transesteri fi cation of palm oil to biodiesel using rice husk ash-based catalysts. Fuel Process. Technol. 2015, 133, 8-13. [CrossRef]

32. Chen, K.; Wang, J.; Dai, Y.; Wang, P.; Liou, C.; Nien, C.; Wu, J.; Chen, C. Journal of the Taiwan Institute of Chemical Engineers Rice husk ash as a catalyst precursor for biodiesel production. J. Taiwan Inst. Chem. Eng. 2013, 44, 622-629. [CrossRef]

33. Roschat, W.; Siritanon, T.; Yoosuk, B.; Promarak, V. Rice husk-derived sodium silicate as a highly efficient and low-cost basic heterogeneous catalyst for biodiesel production. Energy Convers. Manag. 2016, 119, 453-462. [CrossRef]

34. Angin, D.; Şensöz, S. Effect of Pyrolysis Temperature on Chemical and Surface Properties of Biochar of Rapeseed (Brassica napus L.). Int. J. Phytoremed. 2014, 16, 684-693. [CrossRef]

35. Weber, K.; Quicker, P. Properties of biochar. Fuel 2018, 217, 240-261. [CrossRef]

36. Wang, A.; Li, H.; Pan, H.; Zhang, H.; Xu, F.; Yu, Z.; Yang, S. Efficient and green production of biodiesel catalyzed by recyclable biomass-derived magnetic acids. Fuel Process. Technol. 2018, 181, 259-267. [CrossRef]

37. Zhang, F.; Tian, X.F.; Fang, Z.; Shah, M.; Wang, Y.T.; Jiang, W.; Yao, M. Catalytic production of Jatropha biodiesel and hydrogen with magnetic carbonaceous acid and base synthesized from Jatropha hulls. Energy Convers. Manag. 2017, 142, 107-116. [CrossRef]

38. Sano, N.; Yamada, K.; Tsunauchi, S.; Tamon, H. A novel solid base catalyst for transesterification of triglycerides toward biodiesel production: Carbon nanohorn dispersed with calcium ferrite. Chem. Eng. J. 2017, 307, 135-142. [CrossRef]

39. Chellappan, S.; Nair, V.; Sajith, V.; Aparna, K. Synthesis, optimization and characterization of biochar based catalyst from sawdust for simultaneous esterification and transesterification. Chin. J. Chem. Eng. 2018, 26, 2654-2663. [CrossRef]

40. Zhao, C.; Lv, P.; Yang, L.; Xing, S.; Luo, W.; Wang, Z. Biodiesel synthesis over biochar-based catalyst from biomass waste pomelo peel. Energy Convers. Manag. 2018, 160, 477-485. [CrossRef]

41. Mendonça, I.M.; Paes, O.A.R.L.; Maia, P.J.S.; Souza, M.P.; Almeida, R.A.; Silva, C.C.; Duvoisin, S.; de Freitas, F.A. New heterogeneous catalyst for biodiesel production from waste tucumã peels (Astrocaryum aculeatum Meyer): Parameters optimization study. Renew. Energy 2019, 130, 103-110. [CrossRef]

42. Li, X.F.; Zuo, Y.; Zhang, Y.; Fu, Y.; Guo, Q.X. In situ preparation of $\mathrm{K}_{2} \mathrm{CO}_{3}$ supported Kraft lignin activated carbon as solid base catalyst for biodiesel production. Fuel 2013, 113, 435-442. [CrossRef]

43. Putra, M.D.; Irawan, C.; Udiatoro; Ristianingsih, Y.; Nata, I.F. A cleaner process for biodiesel production from waste cooking oil using waste materials as a heterogeneous catalyst and its kinetic study. J. Clean. Prod. 2018, 195, 1249-1258. [CrossRef]

44. Mansir, N.; Teo, S.H.; Rashid, U.; Taufiq-Yap, Y.H. Efficient waste Gallus domesticus shell derived calcium-based catalyst for biodiesel production. Fuel 2018, 211,67-75. [CrossRef]

45. Ezzah-Mahmudah, S.; Lokman, I.M.; Saiman, M.I.; Taufiq-Yap, Y.H. Synthesis and characterization of $\mathrm{Fe}_{2} \mathrm{O}_{3} / \mathrm{CaO}$ derived from Anadara Granosa for methyl ester production. Energy Convers. Manag. 2016, 126, 124-131. [CrossRef]

46. Dantas, J.; Leal, E.; Cornejo, D.R.; Kiminami, R.H.G.A.; Costa, A.C.F.M. Biodiesel production evaluating the use and reuse of magnetic nanocatalysts $\mathrm{Ni}_{0.5} \mathrm{Zn}_{0.5} \mathrm{Fe}_{2} \mathrm{O}_{4}$ synthesized in pilot-scale. Arab. J. Chem. 2018. [CrossRef]

47. Gardy, J.; Rehan, M.; Hassanpour, A.; Lai, X.; Nizami, A.-S. Advances in nano-catalysts based biodiesel production from non-food feedstocks. J. Environ. Manag. 2019, 249, 109316. [CrossRef]

48. Tan, Y.H.; Abdullah, M.O.; Nolasco Hipolito, C. Comparison of Biodiesel Production between Homogeneous and Heterogeneous Base Catalysts. Appl. Mech. Mater. 2016, 833, 71-77. [CrossRef] 
49. Zhang, P.; Han, Q.; Fan, M.; Jiang, P. Applied Surface Science Magnetic solid base catalyst CaO/CoFe $2 \mathrm{O}_{4}$ for biodiesel production: Influence of basicity and wettability of the catalyst in catalytic performance. Appl. Surf. Sci. 2014, 317, 1125-1130. [CrossRef]

50. Abdullah, M.O.; Nolasco-Hipolito, C.; Taufiq-Yap, Y.H. Waste ostrich- and chicken-eggshells as heterogeneous base catalyst for biodiesel production from used cooking oil: Catalyst characterization and biodiesel yield performance. Appl. Energy 2015, 160, 58-70.

51. Teo, S.H.; Rashid, U.; Thomas Choong, S.Y.; Taufiq-Yap, Y.H. Heterogeneous calcium-based bimetallic oxide catalyzed transesterification of Elaeis guineensis derived triglycerides for biodiesel production. Energy Convers. Manag. 2017, 141, 20-27. [CrossRef]

52. Dhawane, S.H.; Kumar, T.; Halder, G. Recent advancement and prospective of heterogeneous carbonaceous catalysts in chemical and enzymatic transformation of biodiesel. Energy Convers. Manag. 2018, 167, 176-202. [CrossRef]

53. Zhang, S.; Su, Y.; Zhu, S.; Zhang, H.; Zhang, Q. Effects of pretreatment and $\mathrm{FeCl}_{3}$ preload of rice husk on synthesis of magnetic carbon composites by pyrolysis for supercapacitor application. J. Anal. Appl. Pyrolysis 2018, 135, 22-31. [CrossRef]

54. Boz, N.; Degirmenbasi, N.; Kalyon, D.M. Transesterification of canola oil to biodiesel using calcium bentonite functionalized with K compounds. Appl. Catal. B Environ. 2013, 138, 236-242. [CrossRef]

55. Balasundram, V.; Ibrahim, N.; Kasmani, R.M.; Hamid, M.K.A.; Isha, R.; Hasbullah, H.; Ali, R.R. Thermogravimetric catalytic pyrolysis and kinetic studies of coconut copra and rice husk for possible maximum production of pyrolysis oil. J. Clean. Prod. 2018, 167, 218-228. [CrossRef]

56. Liou, T.H. Preparation and characterization of nano-structured silica from rice husk. Mater. Sci. Eng. A 2004, 364, 313-323. [CrossRef]

57. Mansaray, K.G.; Ghaly, A.E. Thermal degradation of rice husks in nitrogen atmosphere. Bioresour. Technol. 1998, 65, 13-20. [CrossRef]

58. Biswas, B.; Pandey, N.; Bisht, Y.; Singh, R.; Kumar, J.; Bhaskar, T. Pyrolysis of agricultural biomass residues: Comparative study of corn cob, wheat straw, rice straw and rice husk. Bioresour. Technol. 2017, 237, 57-63. [CrossRef]

59. Yadav, M.; Sharma, Y.C. Process optimization and catalyst poisoning study of biodiesel production from kusum oil using potassium aluminum oxide as efficient and reusable heterogeneous catalyst. J. Clean. Prod. 2018, 199, 593-602. [CrossRef]

60. Khelifi, S.; Ayari, F.; Hassan Chehimi, D.B.; Trabelsi-Ayadi, M. Synthesis and Characterization of Heterogeneous Catalysts and Comparison to Iron-ore. J. Chem. Eng. Process Technol. 2016, 7, 1-9.

61. Santana Costa, J.A.; Paranhos, C.M. Systematic evaluation of amorphous silica production from rice husk ashes. J. Clean. Prod. 2018, 192, 688-697. [CrossRef]

62. Touhami, D.; Zhu, Z.; Sinan, W.; Janaun, J.; Haywood, S. Journal of Environmental Chemical Engineering Characterization of rice husk-based catalyst prepared via conventional and microwave carbonisation. J. Environ. Chem. Eng. 2017, 5, 2388-2394. [CrossRef]

63. Dai, Y.; Wang, Y.; Chen, C. Synthesis and characterization of magnetic $\mathrm{LiFe}_{5} \mathrm{O}_{8}-\mathrm{LiFeO}_{2}$ as a solid basic catalyst for biodiesel production. Catal. Commun. 2018, 106, 20-24. [CrossRef]

64. Fadhil, A.B.; Al-Tikrity, E.T.B.; Khalaf, A.M. Transesterification of non-edible oils over potassium acetate impregnated $\mathrm{CaO}$ solid base catalyst. Fuel 2018, 234, 81-93. [CrossRef]

65. Ambat, I.; Srivastava, V.; Haapaniemi, E.; Sillanpää, M. Nano-magnetic potassium impregnated ceria as catalyst for the biodiesel production. Renew. Energy 2019, 139, 1428-1436. [CrossRef]

66. Yadav, M.; Mishra, N.; Sharma, N.; Chandra, S.; Kumar, D. Spectrochimica Acta Part A: Molecular and Biomolecular Spectroscopy Microwave assisted synthesis, characterization and biocidal activities of some new chelates of carbazole derived Schiff bases of cadmium and tin metals. Spectrochim. Acta Part A Mol. Biomol. Spectrosc. 2014, 132, 733-742. [CrossRef]

67. Wang, L.; Wang, W.; Wang, Y.; Wang, T.; Zhou, S.; Hu, L.; Liu, T.; Elfalleh, W.; Yu, D. Structural characteristics of a Ni-Ag magnetic catalyst and its properties in soybean oil hydrogenation. Food Bioprod. Process. 2018, 109, 139-147. [CrossRef]

68. Farooq, M.; Ramli, A.; Subbarao, D. Biodiesel production from waste cooking oil using bifunctional heterogeneous solid catalysts. J. Clean. Prod. 2013, 59, 131-140. [CrossRef] 
69. Liu, H.; Guo, H.S.; Wang, X.J.; Jiang, J.Z.; Lin, H.; Han, S.; Pei, S.P. Mixed and ground KBr-impregnated calcined snail shell and kaolin as solid base catalysts for biodiesel production. Renew. Energy 2016, 93, 648-657. [CrossRef]

70. Zeng, D.; Liu, S.; Gong, W.; Wang, G.; Qiu, J.; Chen, H. Applied Catalysis A: General Synthesis, characterization and acid catalysis of solid acid from peanut shell. Appl. Catal. A Gen. 2014, 469, 284-289. [CrossRef]

71. Singh, R.; Kumar, A.; Sharma, Y.C. Biodiesel synthesis from microalgae (Anabaena PCC 7120) by using barium titanium oxide $\left(\mathrm{Ba}_{2} \mathrm{TiO}_{4}\right)$ solid base catalyst. Bioresour. Technol. 2019, 287, 121357. [CrossRef]

72. Naveenkumar, R.; Baskar, G. Biodiesel production from Calophyllum inophyllum oil using zinc doped calcium oxide (Plaster of Paris) nanocatalyst. Bioresour. Technol. 2019, 280, 493-496. [CrossRef] [PubMed]

73. Boro, J.; Konwar, L.J.; Thakur, A.J.; Deka, D. Ba doped CaO derived from waste shells of T striatula (TS-CaO) as heterogeneous catalyst for biodiesel production. Fuel 2014, 129, 182-187. [CrossRef]

74. Farooq, M.; Ramli, A.; Naeem, A.; Mahmood, T.; Ahmad, S.; Humayun, M.; Islam, M.G.U. Biodiesel production from date seed oil (Phoenix dactylifera L.) via egg shell derived heterogeneous catalyst. Chem. Eng. Res. Des. 2018, 132, 644-651. [CrossRef]

75. Abukhadra, M.R.; Sayed, M.A. K+trapped kaolinite $(\mathrm{Kaol} / \mathrm{K}+)$ as low cost and eco-friendly basic heterogeneous catalyst in the transesterification of commercial waste cooking oil into biodiesel. Energy Convers. Manag. 2018, 177, 468-476. [CrossRef]

76. Essamlali, Y.; Amadine, O.; Fihri, A.; Zahouily, M. Sodium modified fluorapatite as a sustainable solid bi-functional catalyst for biodiesel production from rapeseed oil. Renew. Energy 2019, 133, 1295-1307. [CrossRef]

77. Satyanarayana, C.V.; Srikant, D.; Gurav, H.R. Catalyst Deactivation and Regeneration. Ind. Catal. Process. Fine Spec. Chem. 2016, 5, 187-219.

78. Gardy, J.; Hassanpour, A.; Lai, X.; Ahmed, M.H. Synthesis of $\mathrm{Ti}\left(\mathrm{SO}_{4}\right) \mathrm{O}$ solid acid nano-catalyst and its application for biodiesel production from used cooking oil. Appl. Catal. A Gen. 2016, 527, 81-95. [CrossRef]

79. Tariq, M.; Ali, S.; Ahmad, F.; Ahmad, M.; Zafar, M.; Khalid, N.; Khan, M.A. Identification, FT-IR, NMR (1H and 13C) and GC/MS studies of fatty acid methyl esters in biodiesel from rocket seed oil. Fuel Process. Technol. 2011, 92, 336-341. [CrossRef]

80. Martínez, A.; Mijangos, G.E.; Romero-Ibarra, I.C.; Hernández-Altamirano, R.; Mena-Cervantes, V.Y. In-situ transesterification of Jatropha curcas L. seeds using homogeneous and heterogeneous basic catalysts. Fuel 2019, 235, 277-287. [CrossRef]

81. Torres-Rodríguez, D.A.; Romero-Ibarra, I.C.; Ibarra, I.A.; Pfeiffer, H. Biodiesel production from soybean and Jatropha oils using cesium impregnated sodium zirconate as a heterogeneous base catalyst. Renew. Energy 2016, 93, 323-331. [CrossRef]

82. Fernandes, S.A.; Cardoso, A.L.; Da Silva, M.J. A novel kinetic study of $\mathrm{H}_{3} \mathrm{PW}_{12} \mathrm{O}_{40}$-Catalyzed oleic acid esterification with methanol via 1H NMR spectroscopy. Fuel Process. Technol. 2012, 96, 98-103. [CrossRef]

83. Yadav, M.; Singh, V.; Sharma, Y.C. Methyl transesterification of waste cooking oil using a laboratory synthesized reusable heterogeneous base catalyst: Process optimization and homogeneity study of catalyst. Energy Convers. Manag. 2017, 148, 1438-1452. [CrossRef]

84. Fadhil, A.B.; Aziz, A.M.; Altamer, M.H. Potassium acetate supported on activated carbon for transesterification of new non-edible oil, bitter almond oil. Fuel 2016, 170, 130-140. [CrossRef]

85. Li, J.; Liang, X. Magnetic solid acid catalyst for biodiesel synthesis from waste oil. Energy Convers. Manag. 2017, 141, 126-132. [CrossRef]

86. Boonyuen, S.; Smith, S.M.; Malaithong, M.; Prokaew, A.; Cherdhirunkorn, B.; Luengnaruemitchai, A. Biodiesel production by a renewable catalyst from calcined Turbo jourdani (Gastropoda: Turbinidae) shells. J. Clean. Prod. 2018, 177, 925-929. [CrossRef]

87. Mansir, N.; Hwa Teo, S.; Lokman Ibrahim, M.; Yun Hin, T.Y. Synthesis and application of waste egg shell derived $\mathrm{CaO}$ supported W-Mo mixed oxide catalysts for FAME production from waste cooking oil: Effect of stoichiometry. Energy Convers. Manag. 2017, 151, 216-226. [CrossRef]

(C) 2020 by the authors. Licensee MDPI, Basel, Switzerland. This article is an open access article distributed under the terms and conditions of the Creative Commons Attribution (CC BY) license (http://creativecommons.org/licenses/by/4.0/). 